Synthesis, part of a Special Feature on Practicing Panarchy: Assessing Legal Flexibility, Ecological Resilience, and Adaptive Governance in U.S. Regional Water Systems Experiencing Climate Change

\title{
Legal and institutional foundations of adaptive environmental governance
}

\author{
Daniel A. DeCaro ${ }^{1}$, Brian C. Chaffin ${ }^{2}$, Edella Schlager ${ }^{3}$, Ahjond S. Garmestani ${ }^{4}$ and J.B. Ruhl ${ }^{5}$
}

\begin{abstract}
Legal and institutional structures fundamentally shape opportunities for adaptive governance of environmental resources at multiple ecological and societal scales. Properties of adaptive governance are widely studied. However, these studies have not resulted in consolidated frameworks for legal and institutional design, limiting our ability to promote adaptation and social-ecological resilience. We develop an overarching framework that describes the current and potential role of law in enabling adaptation. We apply this framework to different social-ecological settings, centers of activity, and scales, illustrating the multidimensional and polycentric nature of water governance. Adaptation typically emerges organically among multiple centers of agency and authority in society as a relatively self-organized or autonomous process marked by innovation, social learning, and political deliberation. This self-directed and emergent process is difficult to create in an exogenous, top-down fashion. However, traditional centers of authority may establish enabling conditions for adaptation using a suite of legal, economic, and democratic tools to legitimize and facilitate self-organization, coordination, and collaboration across scales. The principles outlined here provide preliminary legal and institutional foundations for adaptive environmental governance, which may inform institutional design and guide future scholarship.
\end{abstract}

Key Words: adaptive governance; climate change; design principles; environmental law; social-ecological resilience; state-reinforced selfgovernance; water governance

\section{INTRODUCTION}

To cope with stressors like climate change, economic instability, and socio-political or ideological shifts, environmental governance needs to formally embrace a broader set of environmental actors, organizations, and institutions, and become more flexible, responsive, and innovative (Folke et al. 2005, Chaffin and Gunderson 2016). Vital natural resources are collapsing throughout the world because of unsustainable environmental practices (MEA 2005, FAO 2012) driven by outdated conceptions of nature (Clark et al. 1979, Garmestani and Allen 2014), antiquated assumptions about political engagement (Bingham et al. 2005, Ostrom 2010), rigid and poorfitting policies (Folke et al. 2007, Arnold and Gunderson 2013), and failure of traditional modes of environmental governance to tolerate uncertainty, or adapt to changing social and environmental conditions (e.g., Ruhl 2011, Cosens et al. 2014). These shortcomings threaten human welfare (Dietz et al. 2009) by contributing to poverty, conflict, and degraded societal conditions (IUCN 1980, 2008). Adaptive governance, as a concept (Chaffin et al. 2014a), seeks to overcome these problems by recognizing the need for systemic change, and incorporating elements of learning (e.g., experimentation), collective cooperation, and human ingenuity (e.g., creativity; Westley et al. 2011, 2013).

Adaptive governance often emerges among multiple centers of agency and authority in society as a relatively self-organized or autonomous process (Chaffin and Gunderson 2016). Such adaptation is often triggered by crisis (Gunderson et al. 1995) or to address voids left by more traditional forms of governance (Ostrom 1990, 2010, Lubell et al. 2002). Hence, adaptation remains highly fragmented and uncoordinated (e.g., Tobin 1999), as many different environmental stakeholders seek to address the specific problems and social-ecological conditions that have shaped their situation (Folke et al. 2005). As such, "adaptive governance" has historically been more of a fragmented and reactive process, i.e., adaptation, than a formalized and coherent governance system, or approach (Chaffin et al. 2014a).

Governance systems can theoretically be designed to facilitate and embrace adaptation, helping society navigate important transitions more gracefully (Shivakumar 2005, Cosens et al. 2017). Most environmental stakeholders, ranging from government agencies to grassroots organizations, have some inherent capacity for innovation, decision making, and governance (e.g., Ostrom 1990, 1992). Many scholars argue that some legal and institutional, or rule-governed, oversight (Wheeler 2000, Dietz et al. 2003, Ruhl 2011), or built-in mechanisms for adaptation, for example in the law (Arnold and Gunderson 2013, Clarvis et al. 2014, Craig and Ruhl 2014), could facilitate, and perhaps coordinate, this inherent potential for adaptation, improving adaptive governance. Specifically, traditional centers of authority, like federal and state government, could create laws and legal frameworks to enhance the ability, authority, and resources, i.e., adaptive capacity, of existing environmental stakeholders to make important decisions and flexibly respond to changing social-ecological conditions (e.g., Shivakumar 2005, Clarvis et al. 2014, Cosens et al. 2017).

One of the biggest challenges for this vision of adaptive governance is to develop formal legal frameworks-legal principles, laws, and regulatory mechanisms - that support such adaptation without stifling stakeholders' inherent self-organizing potential or the emergent properties of adaptation itself. The current article addresses this problem by developing an overarching framework to conceptualize and analyze the current and potential role of law in creating favorable conditions for adaptation, across multiple stakeholders and centers of

${ }^{1}$ Department of Urban and Public Affairs, Department of Psychological and Brain Sciences, University of Louisville, Louisville, KY, USA, ${ }^{2}$ College of Forestry \& Conservation, University of Montana, Missoula, MT, USA, ${ }^{3}$ Professor, School of Government and Public Policy, The University of Arizona, Tucson, AZ, USA, ${ }^{4}$ Environmental Protection Agency, Cincinnati, OH, USA, ${ }^{5}$ Vanderbilt University Law School, Nashville, TN, USA 
governance activity. We build on prior work by combining theories of ecological resilience (e.g., Holling 2001), adaptive law (e.g., Craig 2010, Ruhl 2011), self-governance (e.g., Ostrom 1990), and state-reinforced self-governance, which is the concept of traditional government actively supporting self-governance of grassroots stakeholders (e.g., Sarker 2013). We also outline legal and institutional design principles for adaptive governance. These design principles are preliminary and nonexhaustive, but illustrate some important ways traditional centers of authority can create enabling conditions for adaptation, using a suite of complementary legal, economic, and democratic tools, which authorize, fund, and complement greater decision making and problem-solving capacity of environmental stakeholders. The analytical conventions developed in this article are intended to provide vital guidance for future research.

Given the interdisciplinary nature of this project, we think it is important to first explain how we synthesize the many concepts, analytical frameworks, and empirical findings that are the basis for the current framework. We then introduce our interpretation of "emergence," "self-organization," and "adaptation," which the proposed framework seeks to facilitate, using legal and institutional foundations. Afterward, we discuss the concepts of ecological resilience and adaptive cycles, which we used to conceptualize dynamics of adaptive governance. We focus on water governance throughout the article, because water resources play an increasingly critical role in resource scarcity challenges worldwide (Garrick et al. 2013, UNESCO 2015). The current work arose from the Adaptive Water Governance Project (Cosens et al. 2014), an interdisciplinary team of legal scholars, ecologists, and social scientists who sought to understand how current legal and institutional systems contribute to adaptive (or maladaptive) environmental governance within six United States watershed basins. After introducing these conventions, we outline the candidate design principles and illustrate their potential application in cases spanning different areas of law, centers of governance activity, social-ecological systems (SESs), and scales. We conclude with future directions, providing guidance for further refinement and exploration.

\section{OVERVIEW OF SYNTHESIS: CONCEPTUAL AND ANALYTIC FRAMEWORK}

The characteristics of adaptive governance (Dietz et al. 2003, Brunner et al. 2005, Folke et al. 2005, Ruhl 2011), self-governance (Ostrom 1990, 2014), and the adaptive management of environmental resource systems (Holling 1978, Allen and Garmestani 2015) have been widely studied (Cox et al. 2010, Chaffin et al. 2014a). Generally speaking, adaptive processes are flexible, e.g., open to revision, iterative decision making, and experimentation; innovative; participatory; and "polycentric," or spread across multiple centers of activity, social networks, and environmental stakeholders in a pluralistic decision-making context (Armitage 2007, Pahl-Wostl 2009). Thus, whereas many scholars have asked, "What is adaptive governance? What are its core characteristics?" (Chaffin et al. 2014a), very few have examined how adaptive governance may be facilitated by legal frameworks and other institutional ("rule-governed") structures (Shivakumar 2005, Sarker 2013; see also, Cosens et al. 2017).

To explore legal and institutional foundations of adaptive governance, we found it useful to think about adaptation in terms of its emergent and self-organizing properties. We developed a novel convention of "emergence frontiers" to conceptualize opportunities and constraints placed on emergence in SESs by legal and institutional structures and processes. We also adopted and adapted Ostrom's (2005, 2010) concepts of "selfgovernance" and "action situations," as well as Sarker's (2013) concept of "state-reinforced self-governance," to conceptualize how legal and institutional factors in particular social-ecological settings influence environmental decision making and cooperative aspects of emergence and self-organization. Ostrom and Sarker's conventions provide insight into broader sociopolitical, cooperative, and institutional aspects of governance, grounded in the existing work of Ostrom Institutional Analyses (Cole and McGinnis 2015). Our framework also draws from a range of disciplinary traditions, including dynamic federalism (e.g., Engel 2006) and reflexive law (e.g., Ruhl 2011, Garmestani and Benson 2013), new governance (e.g., Bingham et al. 2005), political economy (e.g., Schlager et al. 2012), and public participation and social justice research (e.g., Cosens 2013, DeCaro and Stokes 2013), in addition to research on resilience of complex SESs (e.g., Gunderson and Holling 2002, Ostrom 2014, Chaffin and Gunderson 2016).

The tools and conventions of the proposed framework help to conceptualize complex interactions among the law, institutions, and the environment from an adaptive governance standpoint. Our primary goal is to demonstrate how existing concepts and frameworks can be synthesized, strengthening their analytical and conceptual power, and revealing preliminary design principles that can be investigated to better understand legal and institutional foundations of adaptive governance.

\section{EMERGENCE}

The concept of emergence has been used to describe the innovative and relatively spontaneous nature of adaptive processes in environmental governance (Chaffin and Gunderson 2016). Adaptation often emerges through creative processes initiated by highly motivated or imperiled environmental stakeholders (Gunderson et al. 1995), which range from government agencies and officials, to members of the public, tribal nations, and grassroots organizations (Cosens et al. 2014). All of these stakeholders, and their centers of governance activity, have some capacity for self-organization, in terms of semiautonomous decision making, rule making, and the implementation of solutions. However, these are shaped by existing legal and institutional systems (Ostrom 1971, 1994). Furthermore, some stakeholders are able to self-organize into relatively autonomous groups, e.g., partnerships or social networks, creating or modifying laws, regulatory systems, rules, operational procedures, norms, or a collective vision to manage a social-ecological dilemma (Ostrom 2010, 2014, Sarker 2013). In this paper, we are interested in understanding fundamental enabling conditions of adaptive governance for a range of such centers of governance activity.

\section{Centers of activity}

To illustrate the concept of centers of activity, we discuss watershed governance. Case studies in water governance highlight many stakeholders and governance activities, demonstrating the complexity of SES governance (Cosens et al. 2014). 
For example, grassroots watershed organizations in the U.S. create bylaws, select decision-making boards, and are actively engaged in environmental monitoring, advocacy, and restoration projects; they often monitor formal government agencies and local industry to ensure compliance with water regulations, and advocate for inclusion in important governmental decisions (e.g., Sabatier et al. 2005, Arnold et al. 2014, Chaffin et al. 2014b). Grassroots organizations can emerge with or without formal government support, though support could potentially enhance their work and success (e.g., Koontz and Johnson 2004).

Some communities organize community-based governance systems (Ostrom 1990) that independently manage a resource (e.g., Bardhan 2000), address a watershed problem, or complement formal government activities by filling regulatory or management gaps (Lubell et al. 2002, Benson et al. 2013). Well-organized groups not only adapt (Ostrom 2014), but may also trigger adaptive governance processes throughout a SES, using lawsuits, public advocacy, and other methods to influence legal systems (Wheeler 2000). Grassroots organizers of many kinds, e.g., farmers, tribes, homeowners, and business owners, are frequently instrumental in the formation of emergent governance processes in U.S. river basins (Cosens et al. 2014), for example, the Anacostia (Arnold et al. 2014) and Columbia (Cosens and Fremier 2014).

Government agencies carry out various legal mandates, enforcing the law, and allocating and managing official government resources (Larson et al. 2013). Many agencies are involved in international and interstate river basin compacts, governing transboundary water problems with other government agencies and stakeholders situated in different geopolitical regions (Heikkila et al. 2011, Cosens and Fremier 2014). They also participate in collaboratives with nongovernment stakeholders (e.g., Arnold et al. 2014). Agencies often need more legal, financial, and organizational commitment to engage in self-governing activities (e.g., Craig and Ruhl 2014, Cosens et al. 2017) or contribute to joint governance processes (Genskow and Born 2006). As discussed later, agencies and their legal mandates also sometimes inhibit adaption, undermining other stakeholders' self-governance and generally resisting systemic change (e.g., Marshall 2007), partly because of rigid or unsupportive legal frameworks (e.g., Bingham 2009, 2010).

Bridging structures, like partnerships and compacts, and organizations, like NGOs and universities, frequently serve as liaisons among different centers of activity, helping them to reconcile scales, share information, and coordinate (Cash et al. 2006, Gerlak and Heikkila 2011, Garmestani and Benson 2013). Lack of such bridges contributes to scale mismatches, poor coordination, conflict, and missed opportunities for systemwide coordination and adaptation (e.g., Prager 2010, Chen and Ganapin 2016).

These examples illustrate that there are many centers of activity in environmental governance fulfilling different, potentially complementary, roles that need facilitation from a legal and institutional standpoint. In reality, stakeholders and centers of activity may overlap and interact in complex ways. For example, members of tribal nations can influence river basin governance individually, aggregated into groups, in multistakeholder partnerships, and via more formal compacts and agreements (e.g., Chaffin et al. 2014b). We display some generic examples of these centers of activity and their potential linkages in Figure 1 (see Larson et al. 2013, Sarker 2013 for concrete examples).

As described later, we envision that adaptive governance should seek to facilitate, e.g., authorize and fund, emergent adaptive processes among each of these centers of activity, and enhance their capacity for self-organization and coordination. The purpose of Fig. 1 is to draw attention to the immense scope of this undertaking, identifying important areas for research.

In the current paper, we primarily focus on aspects of law, like the federal Administrative Procedures Act, and predecision assessment statutes like the National Environmental Policy Act, that determine the authority given to governmental and nongovernmental stakeholders to make decisions, create rules, and carry out those solutions (e.g., Craig and Ruhl 2014). We also focus on some aspects of substantive law, which deal with compliance (e.g., Arnold and Gunderson 2013), and aspects of administrative law that influence how members of the general public collaborate with traditional government (e.g., Bingham 2009, 2010), as well as self-govern (e.g., Bingham et al. 2005, Shivakumar 2005). However, we do not address equally important aspects of common law (Ruhl 2011, Green et al. 2014), or discuss foundational aspects of property law or litigation (Arnold and Gunderson 2013), that also influence adaptation and self-organization because these do not focus explicitly on governance scope and authority. Moreover, the design principles that we eventually discuss represent only an important subset of potential principles (Table 1). We selected these principles because they consistently emerged as important aspects of adaptation and semiautonomous self-organization in the case studies we observed in the Adaptive Water Governance Project. They also appear to apply to a broad range of stakeholders and governance activities, representing multiple aspects and functions of law, e.g., administration, regulation, quasi-legislation. Thus, we strive to delineate the core problem and offer some important initial steps toward addressing some major dimensions of it, helping guide future research.

\section{Emergence frontiers}

Because of the self-organizing properties of adaptive governance, we found it useful to think about emergence and adaptation in terms of "emergence frontiers," which are delineated by prevailing legal frameworks and social-ecological conditions. The emergence frontier concept illustrates the expansion and contraction of capacity, authority, and resources - or "space" for adaptation ("adaptive capacity") — within a particular center of activity, as contextualized within an SES and bounded by existing legal conditions (Fig. 2). Legal systems play a major role in creating this space, or latitude, for adaptation by establishing the authority, formal rules, and procedures that government agencies, and other societal stakeholders, e.g., NGOs, industries, or communities, operate within (Bingham 2010, Cosens et al. 2017). For example, Congress delegates substantive authority to U.S. environmental agencies, like the U.S. Fish and Wildlife Service, to manage environmental resources. However, the federal Administrative Procedure Act, predecision assessment statutes like the National 
Fig. 1. Example centers of activity in environmental governance. Layers represent linked social systems or subsystems within society. Rounded boxes (e.g., Federal Gov't) represent centers of environmental governance activity or decision-making situations (e.g., policy making), which may be involved in adaptive governance. Circles represent subunits within centers (e.g., Federal Agencies), and are also decision situations. Arrows depict structural, procedural (e.g., informational, decision-making), and institutional (rule-governed) linkages and interactions; these ties may be strong or weak, depending on context. We assume that centers and layers are linked (not shown for clarity). This representation is not intended to imply a particular priority, or hierarchy, among layers/units; also, it is not exhaustive, but illustrative. Adapted and expanded from Sarker (2013).

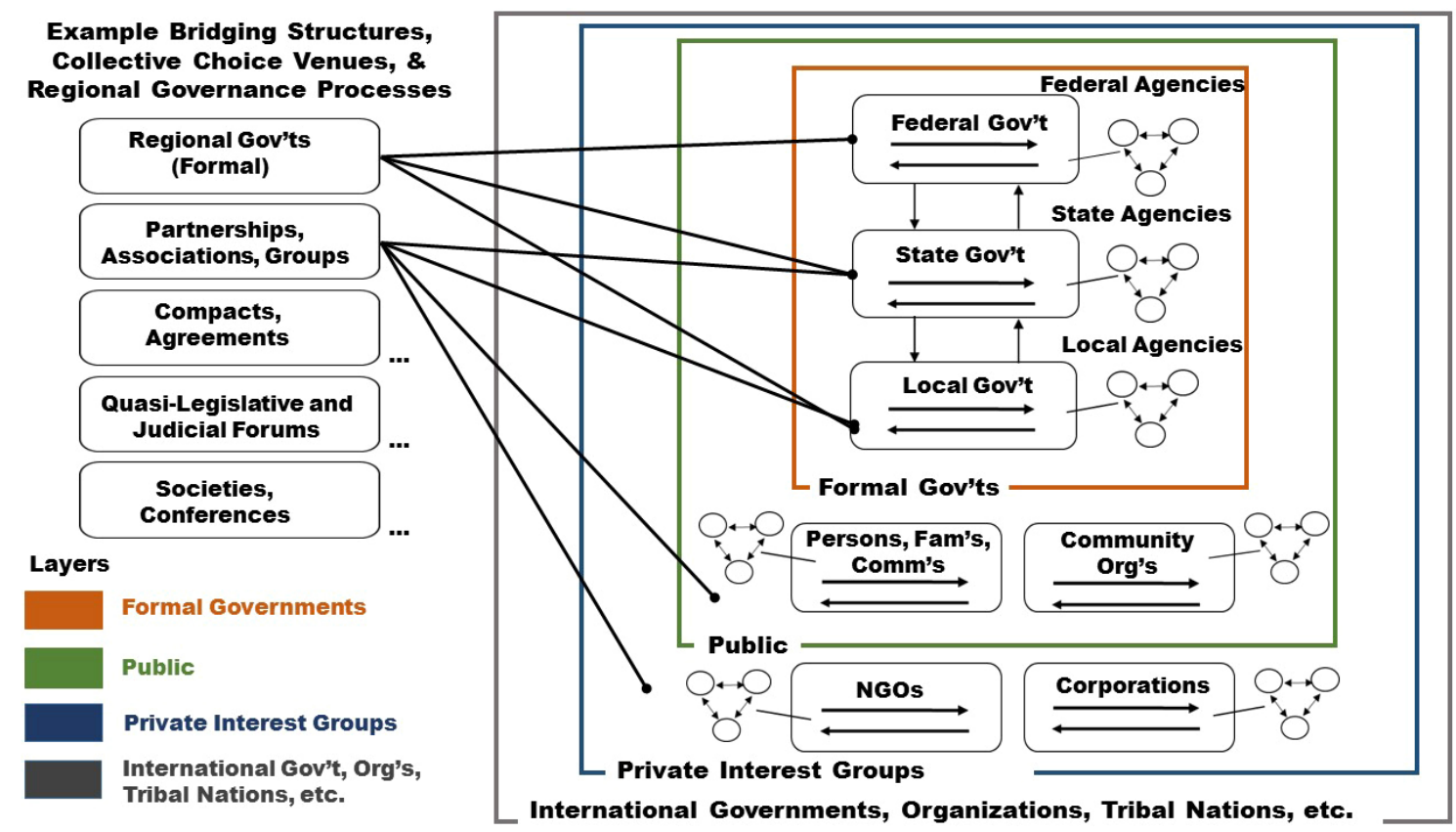

Environmental Policy Act, and other impact assessment steps limit agency self-organization and adaptation by requiring comprehensive upfront cost-benefit analysis, assessment studies, public participation, and judicial review before acting (Craig and Ruhl 2014).

Legal systems and traditional governance authorities are also subject to change and can influence their own adaptation, further contributing to dynamics surrounding emergence frontiers. For example, the federal Administrate Procedures Act, Endangered Species Act, and aspects of the U.S. Constitution, have already undergone some change, altering emergence frontiers of some government agencies as well as nongovernment stakeholder groups and programs (e.g., Arnold and Gunderson 2013, Craig et al. 2017). Moreover, in complex governance systems, legal provisions and governance actors are often embedded in broader governing arrangements, which also shape and constrain emergence in complex ways. For example, in New York City, water quality is governed through a Memorandum of Agreement (MOA) between the City, multiple jurisdictions in the Catskills and Delaware watersheds, and the state of New York (NYC Watershed MOA 1997). Rule-making and permitting processes in this system are governed by different State and City Administrative Procedure Acts, depending on scale; the MOA allows each entity engaged in water quality governance to participate in devising rules and regulations, which impact their interests and the joint cooperative agreement (Platt et al. 2000, Galusha 2002).
We represent these kinds of opportunities and constraints as a solid box in Fig. 2, illustrating how legal provisions and broader governance contexts influence the space in which adaptation can emerge in a "focal center of activity," e.g., a local watershed association. Overly rigid legal provisions may confine, or box in, emergence, pushing the emergence frontier inward and constraining adaptation. However, as just mentioned, legislative and other legal centers of activity can also change and legal systems can adapt (Cosens et al. 2017), further broadening and constraining emergence frontiers in affected centers of activity (illustrated by "//" in Fig. 2). Many factors affect emergence, hence the solid box also signifies the presence of contextualizing factors like politics, economy, culture, and the biophysical environment, which influence environmental governance in particular SESs.

In complex governance systems, the focal center of activity is often linked to other centers of activity (e.g., Larson et al. 2013). We represent these linkages, and their potential effect on emergence in the focal center of activity, using additional boxes situated at different scales (Fig. 2). These linkages ("linked centers") also have emergence frontiers, indicating their potential for adaptation and subsequent effects on other centers and systems. For example, in Fig. 2 we illustrate a local watershed association involved in water governance that is linked with the Environmental Protection Agency, municipal government, and a smaller grassroots organization. 
Table 1. Candidate legal and institutional design principles of adaptive governance.

Legal Design Principles

Reflexive

Does not rely on static rules, e.g., fixed water allocations, when flexibility is needed. Standards, priorities, and procedures guide decision making.

[Example:] National Civic League (2013) amendments to city charters and U.S. Administrative Procedures Act, defining standards of

"adequate" public participation and outlining mechanisms to allow agency discretion in meeting those standards.

Legal Sunsets

Planned periods of comprehensive evaluation, in which environmental policies and agreements can be periodically examined, renegotiated, and potentially modified.

[Example:] Craig and Ruhl (2014) amendments to U.S. Administrative Procedures Act, outlining periods when environmental agencies may test alternative policies, programs, without external review.

Legally Binding Authority

Authority to make decisions and implement chosen solutions is institutionalized in binding legislation, for multiple centers of governance activity in polycentric society, e.g., agencies, communities, regional governments.

[Example:] Land-use laws, giving individual farmers authority to self-organize in increasingly complex collective decision-making structures, parallel to formal government at local, state, and national levels (Sarker 2013).

Legally Binding Responsibility

Formal definition and assignment of responsibility to resolve, or contribute to resolution, of a social-ecological dilemma, or element thereof. [Example:] U.S. State of Oregon requiring local and regional governments to align their development plans with 1970 Statewide Planning Goals (Wheeler 2000).

Tangible Support

Assistance from national, state, and local government, etc., in the form of dedicated and sufficient funds, technology, information, and training to meet one's legally binding responsibilities and pursue one's legally granted authority.

[Example:] Individual farmers (Sarker 2013) and local and regional governments (Wheeler 2000) given tangible assistance from state and national authorities; Coral Reef Conservation Act, providing funding for research, restoration, and technical training for coral reef management (Green et al. 2014).

Institutional Design Principles ${ }^{\dagger}$

Well-Defined Boundaries

Political, institutional, and ecosystem boundaries of the social-ecological dilemma are well defined, clarifying legal and institutional jurisdiction.

[Example:] River compacts (e.g., Platte River, Recovery and Implementation Program; Birge et al. 2014), and water management agreements (e.g., 1997 NYC Watershed Memorandum of Agreement), which clarified sociopolitical, legal, and institutional boundaries, and refined sector, or subsystem jurisdiction (see also, Schlager and Heikkila 2011).

Participatory Decision Making

Variety of participatory methods and processes used so that affected stakeholders can influence design and implementation of governance systems that affect them.

[Example:] National Civic League (2013) and Bingham (2009, 2010) amendments to U.S. Administrative Procedures Act, city charters, etc. to clarify adequate public participation and create more robust legal support for collaborative governance.

Internal Enforcement

In addition to external monitoring and enforcement systems, organizations and collectives, e.g., partners, compacts, communities, have internal mechanisms to monitor and enforce compliance.

[Example:] 2012 NYC Watershed Memorandum of Agreement, South Platte River Compact in context of the Platte River Recovery and Implementation Program (Birge et al. 2014), and traditional community-based irrigation governance (e.g., Cox 2014), which have external and internal mechanisms to monitor and regulate stakeholder compliance, e.g., water usage and deliveries (see also, Heikkila et al. 2011).

Internal Conflict Resolution

Internal mechanisms for neutral and transparent conflict resolution.

[Example:] Traditional community-based irrigation institutions (e.g., Ostrom 1994, Cox 2014), and contemporary polycentric, multistakeholder farmer irrigation collectives (Sarker 2013) that use communication and quasi-formal internal courts to resolve disputes before going to external venues (see also, Schlager and Heikkila 2011).

Primary Source: Ostrom $(1990,2010)$

With this "system of systems" convention (Gianetto and Heydari 2015), one can consider how nonlinear system dynamics, e.g., crisis or surprise, may affect adaptation within and among different centers of governance activity operating at different scales and, indeed, the entire system. For example, we could conceptualize how larger scale dynamics (e.g., modification of federal law), interact with smaller scale dynamics (e.g., modification of rules and norms), within particular governance centers (e.g., grassroots organization, tribal group), or sets of centers (e.g., a multistakeholder decision-making council), affecting individual centers and the entire system.

As just one example, the federal Administrative Procedure Act (larger scale) establishes standards for public involvement (smaller scale) in formal government activities, such as rule making by federal agencies (focal center). Some scholars have criticized these standards for public participation as being poorly defined and very limited, resulting in superficial public 
Fig. 2. Emergence frontiers. Representation of a focal center of activity or decision arena, and its polycentric (linked) connections; explicitly highlights emergence and enabling/constraining features. Circular arrows represent reciprocal connections.

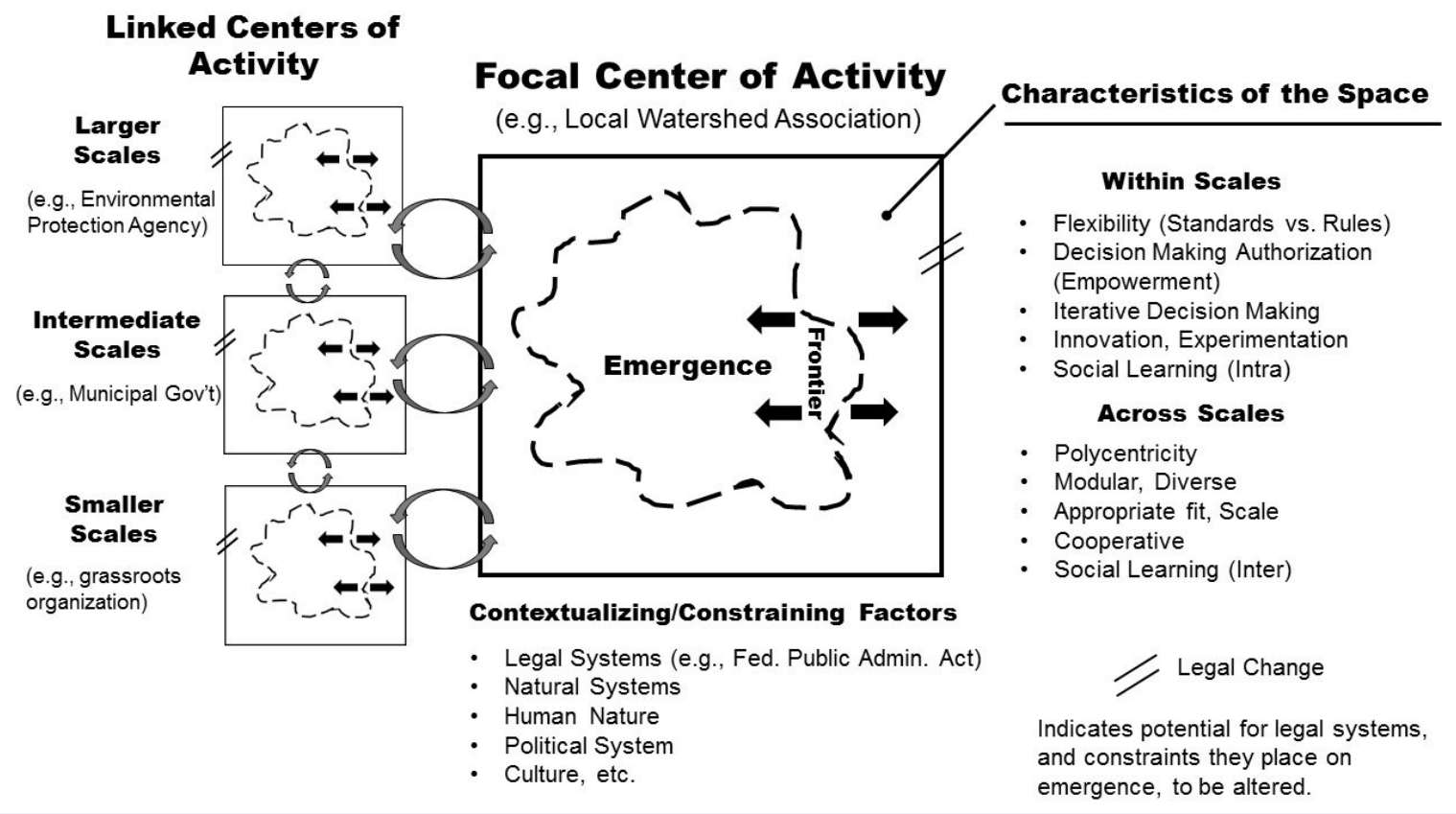

involvement (NCL 2013), which places government agencies in crisis because of public opposition (smaller scale; e.g., Cosens and Fremier 2014) and undermines public-government collaboration (intermediate scales; Bingham 2009, 2010). The interaction of various centers at any scale may ultimately trigger system collapse or failure, either resulting in beneficial adaptation and broadening of emergence frontiers (e.g., Chaffin et al. 2014a) or further rigidity and entrenchment (e.g., Gunderson et al. 2014), depending on other contextualizing factors.

These representations for centers of activity (Fig. 1) and their emergence frontiers (Fig. 2) are complementary to Ostrom's (2009) revised concept of linked action situations, or decision arenas, in SESs (McGinnis and Ostrom 2014), but interpreted through a lens of resilience theory (see below). Whereas Ostrom's action situation focuses on factors influencing self-organization, decision making, and cooperation in socio-environmental dilemmas, the current approach additionally endeavors to emphasize adaptation in complex, dynamic systems. We demonstrate this connection and its usefulness later, when discussing example cases (e.g., Sarker 2013).

\section{RESILIENCE AND ADAPTIVE GOVERNANCE}

Many contemporary approaches to environmental governance oversimplify the complexity and dynamism of SESs (Holling 1973, Olsson et al. 2004). These approaches often seek rigid, onesize-fits-all governance solutions (Ostrom 2007) based on narrow, rigidly linear conceptualizations of system dynamics (Ruhl 2011). In some cases, these rigidities are problematic, hindering adaptive management (Ruhl 2009, 2011). For example, the U.S. Endangered Species Act (ESA) has been criticized as pursuing unrealistic policies to return ecosystems to their "historical" natural conditions in systems already transformed beyond return, precluding more adaptive responses (Doremus 2010). The ESA also emphasizes restoring habitat for single species, often to the exclusion of other species (e.g., Birge et al. 2014), and generally disregards broader social, economic, and political ramifications of the policy, which undermines public support and limits its effectiveness (Arnold and Gunderson 2013). Governance systems and their policies must be responsive to these kinds of social, ecological, and contextual issues (Epstein et al. 2015). Adaptive governance seeks to govern SESs for these complexities, integrating ecological and social system complexity and uncertainty into environmental management and governance activities (Chaffin et al. 2014a).

\section{Resilience}

From a resilience standpoint, one of the primary challenges of adaptive governance is to develop legal frameworks and institutional provisions that can prepare social systems to navigate complex patterns of change and uncertainty (Cosens et al. 2014). Scholars of adaptive governance have therefore adopted principles of resilience to understand patterns of robustness, resistance, and adaptability of governance systems in complex SESs (see Chaffin et al. 2014a for review).

"Resilience" generally refers to the ability of a SES, or component of the system (e.g., governance center), to maintain core processes and functions, even when faced with significant stressors (Gunderson and Holling 2002). There are two major archetypes of resilience (Gunderson 2000). Engineering resilience is defined by recovery, or how rapidly a system can return to its original state after a disturbance. SESs framed by engineering resilience, e.g., hydraulically modified river basins, typically have been 
optimized for a particular purpose, e.g., flood control, within a particular set of conditions, e.g., historic weather patterns, making them effective and resistant to change (rigid) when operating within those specified conditions, but highly susceptible to novel stressors, e.g., climate change, and unable to adapt accordingly. Ecological resilience is a dynamic property of SESs characterized by system diversity, flexibility, and adaptability in response to novel stressors and changing conditions. Ecological resilience allows SESs to withstand a broader range of stressors and operate under more varied conditions, without completely collapsing or undergoing total reorganization.

Ruhl (2011) argues that adaptive governance requires a balance between engineered and ecological resilience, providing both beneficial rigidity, e.g., stability or recovery, and flexibility, e.g., innovation, diversity, and adaptability. Some aspects of legal systems are necessarily relatively more rigid or difficult to alter, e.g., U.S. Constitution, to provide stability, establish societal norms, and reinforce legal processes at different scales. Others may need to be more flexible, e.g., administrative law, interstate river compacts, or specific acts, to cope with dynamism and complexity posed by governance of environmental dilemmas (Arnold and Gunderson 2013, Craig and Ruhl 2014). Resilience of environmental governance also applies to structure, e.g., organizational networks or legal frameworks; content, e.g., policies; and processes, e.g., decision making procedures (Cosens et al. 2017). Adaptation to significant disturbances like climate change may, therefore, entail any combination of rigid and flexible components within and across scales, organizational units, domains of law, and processes of a system (Ruhl 2011, Garmestani and Benson 2013, Craig et al. 2017).

\section{Adaptive governance cycles}

In addition to considering properties that make SESs more resilient, adaptive governance scholars use the concept of an adaptive cycle (Holling 1986) and panarchy (Gunderson and Holling 2002) to understand patterns of change in centers of governance, operating at multiple interacting scales (Chaffin and Gunderson 2016).

Adaptive cycles (Fig. 3) refer to systematic patterns of organization, collapse, and reorganization (innovation, emergence) particular SESs, or their components, may undergo (Holling 1986, 2001). We posit that some governance systems and their institutions, such as legal frameworks, policies, and social norms, follow a similar pattern (Gunderson and Holling 2002, Castro 2012). For example, using the Endangered Species Act and Clean Water Act, Arnold and Gunderson (2013) describe how society at times prefers a particular legal framework (exploitation, $\mathrm{r}$ ), concentrates effort and consolidates resources toward using this preferred solution (conservation, K), then encounters inherent shortcomings that lead to its failure (release, $\Omega$ ), which triggers an opportunity for innovation and reconfiguration, or emergence and adaptation (reorganization, $\alpha$ ). Whether or not and how extensively reorganization occurs depends on many factors (DeCaro et al. 2017). Moreover, as described by panarchy (Gunderson and Holling 2002) and supported by institutional analysis (Anderies et al. 2004, Ostrom 2014), the developmental trajectory of the system is also influenced by linkages to other systems and processes, e.g., political systems or economy, which are in their own phase(s) of adaptation, e.g., economic crisis, at different scales. For example, policies and trajectories at national and regional scales can facilitate or constrain change at smaller scales, and vice-versa (e.g., Wheeler 2000). Different scales can also change at different rates (e.g., Larson et al. 2013).

Fig. 3. Adaptive governance cycle. Representation of dynamic cycles of change ("adaptive cycles") that social-ecological systems (SESs) may undergo: exploitation (r), societal, organizational, or community preference for a particular governance paradigm; conservation $(\mathrm{K})$, consolidation and entrenchment of a preferred paradigm or governance regime; crisis or release $(\Omega)$, shortcomings and failures that lead to paradigm collapse; reorganization $(\alpha)$, opportunity for innovation, which may restructure or transform existing paradigms, yielding novel governance arrangements (emergence, adaptation). Windows of opportunity represent emergence frontiers (Fig. 2), for particular centers of activity (Fig. 1), in a linked SES. Change forces exerted by small and large-scale linkages may be described by panarchy, whereas their legal and institutional dynamics may be described by institutional theory, such as Ostrom Institutional Analysis. Adapted from Chaffin and Gunderson (2016).

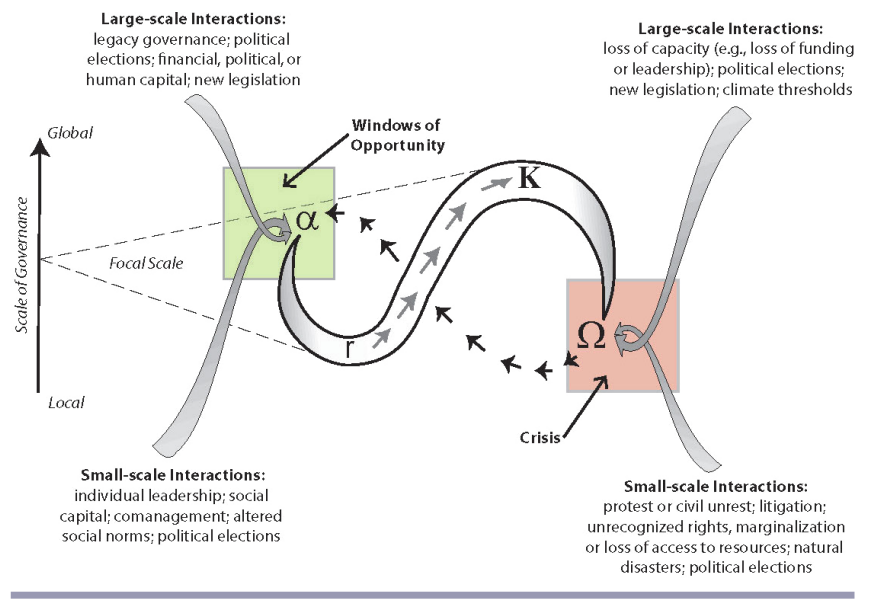

We adopt and expand upon the notion of an adaptive governance cycle, from an interdisciplinary institutional standpoint. Specifically, we hypothesize that governance systems, and their components, i.e., organizations, institutions or processes, evolve in a relatively systematic pattern of growth, entrenchment, collapse, and renewal (Chaffin and Gunderson 2016), but also according to major principles of collective action (Ostrom 2010, 2014).

For example, the Klamath River Basin in south central Oregon and northern California, USA has undergone significant shifts in governance as a result of indigenous displacement, ecological fragmentation, and resource exploitation that contributed to resource crises (Chaffin et al. 2014b). Over the past two decades, allocation of water for irrigation and hydropower has collided with increasing legal recognition of water rights for the basin's indigenous tribes, and their rights to protect habitat of culturally significant fish. This conflict over water uses initially caused crisis (collapse, see Fig. 3), including water scarcity during drought, social and political upheaval, and social justice issues. However, after exhaustion of adversarial options by contesting stakeholder 
groups (reorganization), charismatic leaders from various groups built trust with one another, and new informal networks emerged (window of opportunity), forging new paths toward water sharing and social-ecological restoration (emergence). Though subject to continuing negotiation and adaptation, these new networks and agreements, which entail collective decision making by affected stakeholders, joint resource monitoring and enforcement, and negotiated socio-political and physical boundaries of responsibility, illustrate several principles known to facilitate cooperative resource governance and build trust, demonstrating a connection between adaptive cycles and collective action principles (Ostrom 1992, 2010, Schlager and Heikkila 2011).

These cycles and cross-scale interactions do not necessarily describe dynamics observed in all cases or scales; actual adaptation may be more or less absolute, with multiple factors determining evolutionary trajectory (Davidson 2010). Specific dynamics that unfold in a given system, or scale of analysis, are typically nonlinear and difficult to predict, requiring detailed analyses to fully describe (e.g., Fleishman et al. 2010, Larson et al. 2013). However, the concept of an adaptive governance cycle provides a useful starting point to hypothesize the relationship among multiple scales and interacting systems, which is necessary for designing legal and institutional frameworks that can cope with those dynamics.

\section{Adaptive governance}

In the current paper, we address potential legal and institutional foundations of "adaptive governance," proactive and intentional aspects of governance, like legal systems, e.g., laws or regulatory mechanisms, specifically designed to support adaptation and promote cooperation among different centers of activity (see Dietz et al. 2003, Shivakumar 2005 generally). In the U.S., many stakeholders and centers of governance activity are adapting to climate change, and other stressors, and they have some capacity for self-organization. However, they are doing so within a fragmented and arguably unsupportive legal framework, which can stifle adaptation, e.g., restrict application of adaptive management, limit creativity and cooperation, and contribute to unnecessary societal and environmental catastrophes (Cosens et al. 2014).

We envision a more robust set of legal principles aimed at facilitating a less fragmented and more cooperative, yet still diverse and adaptable, approach to environmental governance. These principles pertain to multiple legal domains, e.g., administrative and substantive law (Ruhl 2011, Cosens et al. 2017), and may potentially be applied across multiple scales and centers of activity, as conceptualized by recent reinterpretations of polycentric, federalist governance (e.g., Shivakumar 2005, Schlager et al. 2011). Because the emergent and self-organizing property of adaptation cannot be replicated in a top-down fashion, we propose that traditional authorities instead strive to create enabling conditions, which are supportive of emergence using appropriate legal and institutional provisions.

\section{CANDIDATE DESIGN PRINCIPLES FOR ADAPTIVE GOVERNANCE}

We envision that traditional centers of authority may establish enabling conditions for adaptation using a suite of legal, economic, and democratic tools to authorize and further support self-organization, and facilitate coordination. As illustrated in Fig. 2, the space created for emergence is characterized by several key attributes, including flexibility, decision making authority, and for larger scales (e.g., regional government) polycentricity, cooperation, and social-ecological fit (Folke et al. 2005, Armitage 2007, Ruhl 2011). We outline candidate legal and institutional design principles for adaptive governance that may help create such a space (see Table 1) and we demonstrate some key elements of these principles in practice, using examples from selected case studies and legal innovations.

We define "design principles" as features of legal and other rulegoverned, i.e., institutional, systems that may be especially important enabling conditions for self-organization and adaptation within complex governance systems. Legal design principles pertain to (a) elements of official legal systems that determine structure, authority, function, and guidelines for government agencies (e.g., administrative law) and private centers of activity (e.g., individuals, industry, grassroots organizations) and (b) rules and regulatory systems that deal with compliance (e.g., substantive law like the Endangered Species Act; see also Clarvis et al. 2014, Cosens et al. 2017 generally). Institutional design principles refer more broadly to features of rule-governed systems, like clearly defined socio-political and geographic boundaries, that help collectives solve problems cooperatively; these principles originate from Ostrom's $(1990,2010)$ analysis of self-governing communities, but may also be applied to more formal, complex governance systems (Schlager and Heikkila 2011, Sarker 2013). It is important to address both types of principles, because most complex governance problems involve both formal and informal stakeholders, governance systems, and processes.

Given the complexity of SESs and the state of current scholarly knowledge, we cannot anticipate every possible design feature for adaptive governance or delve deeply into all aspects of both formal legal principles and institutional principles. Instead, we endeavor to provide an overview of potentially important principles, along with their rationales. These principles are inspired by patterns observed in U.S. river basins (see Cosens et al. 2014 generally), and other SESs. Later, we illustrate concrete mechanisms that embody these principles, as examples. We hope that future research will expand and modify these principles, and identify important boundary conditions.

\section{Legal design principles}

Reflexive law and legal sunsets: iterative decision making

One of law's primary roles is to establish ground rules for society, creating a sense of security and stability, which guides behavior and enables stakeholders to cooperate, solve complex social dilemmas, and plan for the future (Tyler 1990, 2006, Ostrom 1998). Garmestani and Benson (2013) and Craig et al. (2017) suggest that for environmental law to enable more flexible decision making without jeopardizing security or stability (Green et al. 2015), legal systems affected by dynamic stressors like climate change need to emphasize standards and general principles, e.g., proportional water allocation principles, instead of specific rules, e.g. fixed water allocation rules (e.g., Schlager and Heikkila 2011, Clarvis et al. 2014). Craig et al. (2017) refer to this shift as setting "legal floors, legal ceilings, and intelligible principles," which, for example, establish minimum requirements (floors), maximum 
thresholds (ceilings), or general guidelines (principles) to guide decision making without specifying exact solutions that could become outdated or too rigid when social-ecological conditions change (e.g., Benson et al. 2014). These approaches embody aspects of "reflexive law" (Teubner 1983, Orts 1995), which advocates that legal authorities establish goals, standards, and ground rules for engagement, but leave open final solutions, so that decision makers have both the legal guidance and flexibility they need to respond to complex societal dilemmas (Garmestani and Benson 2013). These types of provisions can apply to government agencies (e.g., Craig and Ruhl 2014), transboundary compacts and treaties (e.g., Schlager and Heikkila 2011), and community-based governance systems (e.g., Ostrom 1990, 2014).

Craig et al. (2017) additionally argue that divisions of powers (e.g., federal-state), informal legal norms (e.g., common law), and formal sunsets on existing legal provisions enhance adaptive capacity, specifically by (a) permitting delegation of activities to more appropriate agencies or scales (e.g., public-government collaboratives), (b) allowing incremental revision over long periods of societal development, and (c) creating planned windows of opportunity for transformative adjustment of more weighty provisions, like water compacts and international treaties (e.g., Cosens and Fremier 2014). Government agencies and smaller organizations (e.g., grassroots watershed associations) can both (a) develop inertia, preventing change, and (b) get bogged down in continual scrutiny of their activities (e.g., Gunderson et al. 2014). Planned windows provide a more balanced approach to governance, providing a structured and predictable period to reassess and change direction, thereby safeguarding security and stability without jeopardizing equally important aspects of flexibility and responsiveness. These design principles fit into a larger category of iterative decision making, an essential characteristic of adaptive governance (e.g., Armitage 2007, Clarvis et al. 2014).

\section{Legally binding authority}

Environmental stakeholders operating within their respective centers of activity need some recognized authority to make decisions, carry out plans, and otherwise self-govern (Wheeler 2000, Ostrom 2010, Sarker 2013). Law and traditional centers of authority have a role to play in legitimizing and permitting more decision-making latitude for stakeholders (Cosens 2013). Case studies indicate that adaptive governance systems often organize into a polycentric, but coherent whole, composed of multiple stakeholders, organizations, and structures, e.g., partnerships, that are bound by provisions that legitimize their authority and permit self-organization (e.g., Folke et al. 2005, Sarker 2013). In addition to reflexive law, legal scholars have explored foundations for such a system within dynamic federalism (e.g., Engel 2006, Schlager et al. 2011) and transgovernmental networks theory (e.g., Craik and DiMento 2008). Under dynamic federalism, loosely coordinated centers of authority, like state and federal government agencies, carry and exchange various roles, powers, and responsibilities according to demand (Engel 2006, Adelman and Engel 2011). According to Thomson and Arroyo (2011), this aspect of U.S. government allowed state agencies to begin forging the way for climate change adaptation before federal government entry into the policy realm (Resnik et al. 2011, Schlager 2011).
Transgovernmental networks refer to the formal and informal collaborative networks of governmental and nongovernmental stakeholders that frequently emerge in environmental dilemmas (e.g., Armitage 2007, Arnold et al. 2014). These governance structures and processes may be more effectively directed toward adaptive ends (Ruhl 2011) with formal incorporation in environmental governance (Craik and DiMentio 2008, Erberlein and Newman 2008).

\section{Legally binding responsibility}

Legally binding devolution of responsibility for environmental dilemmas at different governance scales may be a necessary component of effective adaptive governance (e.g., Wheeler 2000, Sarker 2013). Major stakeholders may be motivated to help resolve an environmental dilemma if they are formally vested with the responsibility or perceive themselves as having a stake in it (Ostrom 2010). Thus, legal action can help define and assign responsibility, triggering novel stewardship activity (Cosens et al. 2017). For example, local and regional governments in Portland, Oregon reportedly began sharing resources and working together to meet new state sustainability requirements after the State of Oregon formally required them to align their development plans with its 1970 Statewide Planning Goals (Wheeler 2000). Thus, vesting interdependent stakeholders with new responsibilities fundamentally alters the power dynamics and relationships within a SES, creating change that may encourage coordination (Sarker 2013) even if conflict exists (e.g., Cosens and Fremier 2014).

\section{Tangible support}

However, devolution of responsibility may be overwhelming without genuine decision-making authority or proper technical and financial support (Wheeler 2000). Traditional centers of government may need regulatory tools, such as grants, tax incentives, and penalties (Wheeler 2000, 2009); new administrative standards and procedures (Bingham et al. 2005, Craig and Ruhl 2014); and strengthened commitment to democratic norms, like subsidiarity (Marshall 2007, Cosens 2013) and self-governance (Shivakumar 2005) to support meaningful devolution of responsibility (see also, Ruhl 2011). Lack of administrative and technical support, inadequate legal authority to self-organize, and reluctance of government officials to devolve responsibility (DeCaro et al.2017) are all major factors commonly cited for adaptive and cooperative failures in environmental governance (e.g., Marshall 2007, Clement 2010).

\section{Institutional design principles}

Several principles for adaptive governance arise from Vincent and Elinor Ostrom's examination of polycentric governance in federalist societies (Ostrom 1971, 1999) and community-based environmental governance, or self-governance (Ostrom 1998, 2010). Ostrom Institutional Analysis (Cole and McGinnis 2015) studies how formal governments influence societal capacity to adaptively solve complex problems (Shivakumar 2005). It is important to understand the central role of human behavior and collective action in determining societal outcomes, paying special attention to the inherent conflict, or social dilemma(s), involved in human governance (DeCaro et al. 2017). The fundamental problem, from a collective action standpoint, is creating governance systems that enable otherwise self-interested actors, e.g., political factions and citizens, to cooperatively solve societal problems, despite differences of opinion, societal standing, and 
ability (e.g., Schultz et al. 2015). Rather than look solely to the centralized government, Ostrom Institutional Analysis seeks to understand human capacity for self-organization, in complex governance systems: communities (Ostrom 1990, 1998), municipalities (Ostrom 2000), and federations (Ostrom 1971, 1999, see also, Schlager et al. 2011).

\section{Principles}

Ostrom Institutional Analysis generated several principles that, along with concepts of SES resilience, contributed to early articulations of adaptive governance (Dietz et al. 2003). Ostrom's design principles $(1990,2010)$ are considered important because they increase capacity for adaptive decision making and cooperation (Ostrom 2014) and facilitate emergence of selforganization at smaller scales (e.g., Ostrom 1965, 1992): (a) welldefined political and geographic boundaries for resource management, (b) internal mechanisms for neutral and transparent conflict resolution, (c) participatory decision making that is inclusive and deliberative, and (d) internal mechanisms for monitoring, enforcement, and graduated sanctioning to safeguard essential rules and agreements (Cox et al. 2010). Access to official legal courts is also essential for disputes that cannot be easily settled internally, or informally (Ostrom 1965). Extensive field and laboratory research indicates that these principles promote cooperation by creating a governance context of transparency, credibility, and enforceability, which builds trust, solidifies environmental agreements, and helps maintain productive relationships (Poteete et al. 2010). Many of these principles apply to large-scale, complex systems like regional governments (Wheeler 2000, Schlager and Heikkila 2011) and federations similar to more traditional government structures (Sarker 2013).

\section{Informal norms and practical solutions}

Ostrom Institutional Analysis also stresses the importance of formal and informal norms and institutions in effective governance of SESs (Cole and McGinnis 2015). Self-organizing agents frequently devise "operational" rules, norms, procedures, and technical methods to address significant management issues and to fill voids left by more traditional governments (Ostrom 1990, 2010). These solutions will often be influenced by placebased knowledge - cultural, ecological, organizational - and adapted over time (Ostrom 2014), helping increase their fit and effectiveness at appropriate scales (Ostrom 2007).

\section{Ostrom's analytical frameworks and adaptive governance}

Ostrom $(1990,2007)$ developed frameworks to help researchers systematically catalogue and investigate complex factors shaping self-organization in complex governance systems, comprising multiple scales and centers of activity. For example, Ostrom's (2007) social-ecological system framework (Fig. 4) illustrates linked "action situations"; their associated actors, governance systems, and ecosystems; broader social-ecological context, e.g., historical, political, economic; and underlying system attributes, e.g., ecosystem characteristics. With this tool, researchers can characterize factors and processes affecting adaptive governance in particular systems, specifically from a standpoint of collective action and cooperative decision making (McGinnis and Ostrom 2014). We suggest that this, and other tools like it (e.g., Resilience Alliance 2010), are necessary to understand complex processes underlying emergence (e.g., Larson et al. 2013, Sarker 2013). We also point out that Ostrom's concept of an "action situation" resembles our "emergence frontier" concept (Fig. 2). Ostrom's social-ecological system framework is also compatible with the concept of "adaptive governance cycles" (Fig 3), identifying specific factors that may structure windows of opportunity and crisis (e.g., Anderies and Janssen 2013, Larson et al. 2013). We do not explicitly illustrate application of Ostrom's frameworks here. However, when we illustrate the legal and institutional design principles later, we do discuss a particularly informative case (see Sarker 2013), which may exemplify the approach.

\section{Summary}

In summary, we envision that the legal and institutional design principles outlined here (Table 1) complement one another to create sufficient resources, opportunity, guidance, and authority for robust cooperation and emergence of adaptive governance within society. Principles of reflexive law (e.g., legal standards, floors, and ceilings) support flexibility in decision making, while principles of legally binding devolution of authority give multiple stakeholders legal authority to make and act upon those decisions (Garmestani and Benson 2013, Craig and Ruhl 2014). Technical, financial, and informational assistance give decision makers necessary tools to successfully implement decisions and learn through iterative, experimental processes (Wheeler 2000, Marshall 2007). Factors like well-defined socio-political and geographic boundaries, however difficult to achieve, make management of those systems more feasible, logistically and politically (Ostrom 1990, Moss and Newig 2010). Institutional design principles, like internal mechanisms for dispute resolution, monitoring, and enforcement, coupled with participatory decision making, support stakeholder self-organization and simultaneously generate conditions for procedural fairness, legitimacy, and security needed to cultivate trust and promote cooperation in complex social-ecological dilemmas (DeCaro et al. 2017). Finally, legal sunsets and quasi-legislative and -judicial processes, additionally provide windows of opportunity for adaptation (Craig and Ruhl 2014), and latitude for informal social norms and processes to emerge (Bingham et al. 2005), within semirigid governance systems. If generalized more broadly throughout society (Ostrom 1994, 1997, Shivakumar 2005), and complementarily linked across centers of activity, sectors, and scales (Green et al. 2015), then these design principles-and perhaps more-may establish a set of mutually reinforcing design features that can guide and support adaptive governance.

These legal and institutional design principles are complementary in other ways. First, informal institutional mechanisms for selforganization can coexist with formal legal mechanisms, filling gaps and reinforcing one another (Ostrom 1971, 1999). For example, grassroots watershed organizations often monitor river systems, helping to enforce the Clean Water Act despite lax governmental enforcement, and the Act gives these grassroots organizations indirect authority to do so (e.g., Arnold et al. 2014). Moreover, legal systems and government agencies themselves operate under both formal and informal processes, with capacity for self-organization (Cosens et al. 2017). Operating with Ostrom's institutional principles in mind could improve their effectiveness (Schlager and Heikkila 2011). Second, as illustrated in the next section, scholars are exploring ways that legal systems can support emergence and enable "state-reinforced selfgovernance" by creating supportive laws and legal procedures. 
Fig. 4. Ostrom action situation and social-ecological system framework. Analytical framework for understanding dynamic environmental governance processes in complex social-ecological systems (SESs), or particular centers of activity, analogous to the Adaptive Water Governance Project's Emergence Frontiers convention (Fig. 2), and associated SESs approach. Listed variables indicate categories, and specific instances, of SESs that may shape environmental governance. Source: Reprinted with permission from McGinnis and Ostrom (2014), Ostrom (2009), and The American Association for the Advancement of Science.

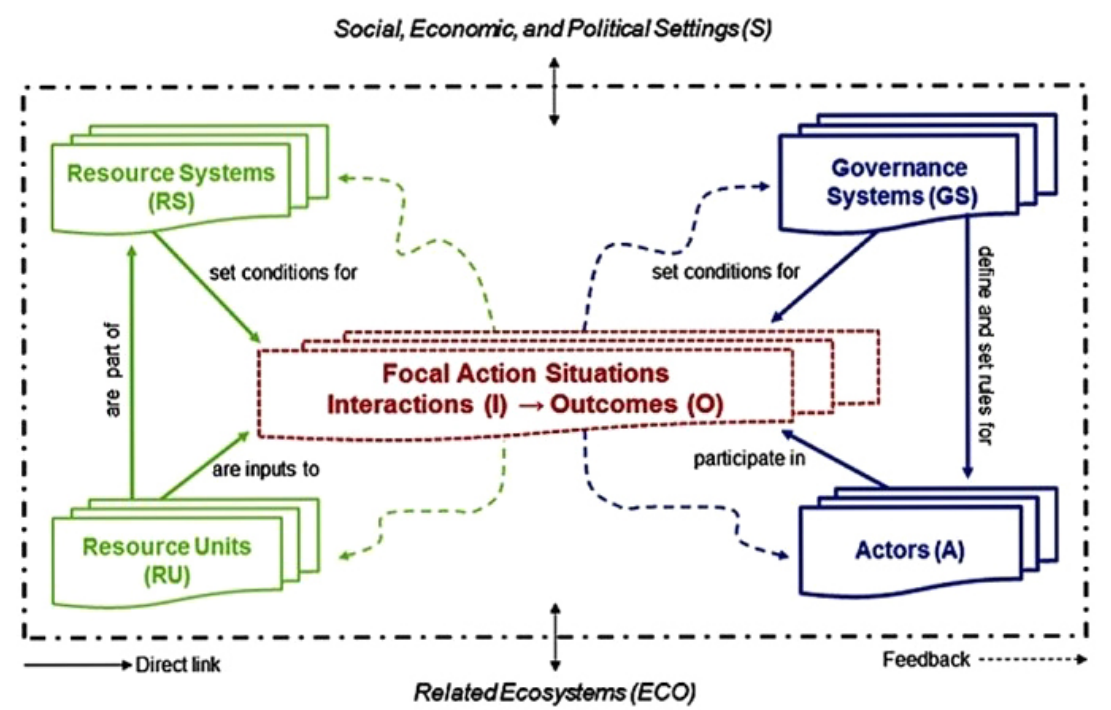

Social, economic, and political settings (S)

S1 Economic development. S2 Demographic trends. S3 Political stability. S4 Government resource policies. S5 Market incentives. S6 Media organization.

\begin{tabular}{ll}
\hline & \multicolumn{1}{c}{ Resource systems (RS) } \\
RS1 & Sector (e.g., water, forests, pasture, fish) \\
RS2 & Clarity of system boundaries \\
RS3 & Size of resource system \\
RS4 & Human-constructed facilities \\
RS5 & Productivity of system** \\
RS6 & Equilibrium properties \\
RS7 & Predictability of system dynamics \\
RS8 & Storage characteristics \\
RS9 & Location \\
& \multicolumn{1}{c}{ Resource units (RU) } \\
RU1 & Resource unit mobility * \\
RU2 & Growth or replacement rate \\
RU3 & Interaction among resource units \\
RU4 & Economic value \\
RU5 & Number of units \\
RU6 & Distinctive markings \\
RU7 & Spatial \& temporal distribution
\end{tabular}
Governance systems (GS)
GS1 Government organizations
GS2 Nongovernment organizations
GS3 Network structure
GS4 Property-rights systems
GS5 Operational rules
GS6 Collective-choice rules*
GS7 Constitutional rules
GS8 Monitoring and sanctioning processes

Interactions $(I) \rightarrow$ Outcomes $(O)$
I1 Harvesting levels of diverse users
12 Information sharing among users
I3 Deliberation processes
14 Conflicts among users
15 Investment activities
16 Lobbying activities
17 Self-organizing activities
O1 Social performance measures (e.g., efficiency, equity, accountability, sustainability) overharvested, resilience, biodiversity, sustainability)
O3 Externalities to other SESs
O2 Ecological performance measures (e.g.,

I8 Networking activities

\section{Users $(U)$}

U1 Number of users

U2 Socioeconomic attributes of users

U3 History of use

U4 Location

U5 Leadership/entrepreneurship*

U6 Norms/social capital ${ }^{*}$

U7 Knowledge of SES/mental models

U8 Importance of resource

U9 Technology used

Related ecosystems (ECO) ECO1 Climate patterns. ECO2 Pollution patterns. ECO3 Flows into and out of focal SES

*Subset of variables found to be associated with self-organization 
For example, new legislation could clarify and enhance participatory decision making (NCL 2013) and public participation in governmental collaboration (Bingham 2009, 2010); expand the use of quasi-legislative and -judicial processes, like citizen juries and participatory budgeting, which support community-based governance (Bingham et al. 2005); and grant nongovernment stakeholders more authority to manage, regulate, and enforce some aspects of ecosystem management and environmental policy (Goddard et al. 2010, Sarker 2013).

\section{DEMONSTRATION OF DESIGN PRINCIPLES}

We begin by reviewing a fairly comprehensive case study by Sarker (2013), which illustrates most of the principles in a large-scale, polycentric governance system. The Sarker example is also important because it introduces the concept of "state-reinforced self-governance," which we believe aptly encapsulates our vision of facilitated adaptive governance. The other examples in this section illustrate different design principles in different legal domains and scales.

There are no complete demonstrations or easy blueprints for adaptive governance (Ostrom 2007, 2014). The cases presented in this section, though not exhaustive, provide an initial proof of concept, with informative examples. Further research is needed to more fully identify particular instances of the design principles, and their potential nuances and shortcomings, in different governance systems, legal domains, and scales. To identify the design principles discussed, we note them in brackets. There are additional examples in Table 1.

\section{Polycentric governance: irrigation commons of Japan}

Sarker (2013) and colleagues (Sarker et al. 2014) describe a polycentric adaptive governance system surrounding irrigation water governance in Japan. The system consists of traditional national, state (prefectural), and local governments, which provide financial, legal, and technical support to a semiautonomous federation of farmers who operate in parallel with traditional forms of governance at these same scales. The farmers manage major irrigation works and water resources for agricultural use. Sarker describes this system as "state-reinforced self-governance," in which traditional governmental authorities, in essence, support the emergence of farmer stakeholder groups in a polycentric system, using complementary legal, administrative, financial, and other tools. This case is also informative because Sarker and colleagues (Sarker 2013, Sarker et al. 2014) used Ostrom's (2007) social-ecological system framework (Fig. 4) to thoroughly analyze the broader SES factors and processes surrounding collective action and cooperative decision making. Hence, we refer readers to the original articles for a detailed demonstration of Ostrom Institutional Analysis, which we believe could be more fully integrated with the current conventions of emergence frontiers and adaptive governance cycles in future research. For now, we focus on illustrating key design principles.

In 1949, the Japanese national government created a Land Improvement Law authorizing irrigation water user associations to manage built infrastructure and water resources in "Land Improvement Districts." These districts exist at the local level, consisting of voluntarily registered farmers with existing (or new) water rights, specified in the law. Water districts are entrusted to manage the water resources and operate built infrastructure for agricultural purposes internally. Hence, they develop their own operational rules and governance procedures, allocate funds, and distribute water within their districts [Legally Binding Authority]. Districts are responsible for $100 \%$ of financial costs associated with local development projects but receive considerable funds from state government when projects benefit society [Tangible Support]. Conflicts are handled internally, unless formal laws are violated [Internal Conflict Resolution]. Organizational and resource monitoring is conducted both internally by elected auditors, and externally by local and state government, helping to support credible and transparent enforcement [Internal Enforcement].

These districts are semiautonomously self-organized using democratic processes, whereby interested farmers bring the possibility of forming an official district organization to regional farmers for public review and agreement [Participatory Decision Making]. The district's official design plan is reviewed by a governor to ensure compliance with the law [Legally Binding Responsibility]. Each year, districts draft a new water management plan based on existing social-ecological conditions, helping them to adapt to change [Legal Sunsets, Reflexive]. Districts elect a representative to serve on a Council of Representatives, which operates at the state level, alongside formal state government. The council makes significant decisions regarding governance of its federated districts; it also acts as liaison with formal government [Participatory Decision Making]. For example, state government agencies commonly share their construction plans with districts and their councils, helping smooth cooperation and coordination. The councils also commission an official Administrative Bureau of experts to provide administrative and technical support [Tangible Support]. There are a total of 5150 districts, organized into 47 of these statelevel units (councils), with 1 national-level unit, which consists of elected council members. These districts and their water governance issues are complex, encompassing multiple actors, geographic characteristics, land uses, and overlapping legal and institutional (sub)systems from more traditional state and nontraditional public centers of governance activity. The legal provisions illustrated in this case span multiple legal domains, including administrative laws that expand and create authority for self-organization, and substantive laws that govern regulation, cooperation, and compliance (see also Sarker et al. 2015).

According to Sarker and colleagues, this system of statereinforced self-governance balances the costs and benefits of collective action within and among state and nonstate actors, enabling robust cooperation and adaptation at multiple scales of environmental governance. These arrangements are reinforced by robust social norms dating back to historic eras of water management in Feudal Japan, which make overreach by traditional governments taboo, but also provide stakeholders with traditional social-ecological knowledge that can inform effective, place-based water management. The Japanese government's willingness to genuinely devolve authority to farmer stakeholders and provide tangible support represents a particular strength of this system, as demonstrably few governments have done so (DeCaro et al. 2017). For example, Marshall (2007) describes a similar system in Australia, which failed to enable emergence, because traditional authorities did not devolve authority genuinely, or provide financial support. 


\begin{abstract}
Administrative law
Legal scholars have identified rigidities in U.S. administrative law at federal and state levels that contribute to ineffective governance and poor adaptation by government agencies (for review see Cosens 2013, Craig and Ruhl 2014). Shortcomings pertain to legitimacy (Cosens 2013), flexibility in environmental management (Craig and Ruhl 2014), and public participation (Bingham 2009), among other issues. We describe proposed amendments to administrative law that may facilitate beneficial emergence within government agencies and support broader public participation and governmental collaboration. These amendments illustrate how some of the design principles could be incorporated in novel legislation for administrative process.
\end{abstract}

Craig and Ruhl (2014) describe how the federal Administrative Procedure Act (APA) and statutes like the National Environmental Protection Act constrain adaptation and selforganization of state and local government agencies in response to major environmental stressors like climate change. Because of these policies, government agencies routinely complete comprehensive predecision assessments, undergo external judicial review, and include at least some minimum public participation whenever they take substantial new action. These procedural requirements can stifle agency creativity and make it difficult for agencies to effectively respond to dynamically changing SESs. These requirements can be further preyed upon by opposition groups to block agency adaptation, for example via crippling lawsuits (e.g., Gunderson et al. 2014).

Craig and Ruhl (2014) outline amendments that may alleviate some of these constraints, without sacrificing democratic public involvement or agency flexibility. First, windows of opportunity for review and public participation could be scheduled periodically, every three to five years, allowing agencies to test alternative environmental practices, without crippling review or continuous public scrutiny [Legal Sunsets] (see Birge et al. 2014 for a case example on the Platte River in Nebraska, USA). Second, only specific types of environmental projects, with high uncertainty (e.g., climate change), rapid change, and controllability (potential for effective human intervention), will be eligible for these more flexible decision-making procedures, helping identify appropriate applications for increased flexibility [Reflexive].

Public participation in formal government is important, but is routinely undermined by government agencies who fear losing control (DeCaro et al. 2017). Hence, there is a challenge to balance agency flexibility and discretion against essential public participation. Bingham $(2009,2010)$ and colleagues (Bingham et al. 2005) outline amendments to the APA, which may complement Craig and Ruhl's (2014) amendments. These adjustments are designed to enhance public participation and collaborative decision making, without paralyzing government agencies [Participatory Decision Making]. Bingham argues that government agencies are able to avoid meaningful public participation, partly because requirements codified by the APA are ambiguous and limited in scope. Government agencies routinely use superficial forms of public engagement, e.g., public hearings, that give citizens virtually no influence on important decisions, and they often ignore public input, or avoid public participation entirely (Arnstein 1969, Bullard and Johnson 2000, Marshall 2007, NCL 2013). Indeed, inadequate public participation, and active marginalization of racial and tribal groups by government agencies, has been identified as a major problem in many U.S. river basins (e.g., Arnold et al. 2014, Chaffin et al. 2014b, Cosens and Fremier 2014).

The National Civic League's (NCL 2013) Working Group on Legal Frameworks for Public Participation has drafted model provisions to help correct this problem. These include a municipal ordinance, city charter, and revisions to state APAs. First, the amendments clarify the standards for adequate public engagement by carefully defining "participation" to encompass broader democratic ideals, identifying types of participation that satisfy those ideals, and outlining best practices to design and implement participation. However, to support agency discretion, the amendments authorize agencies to choose whichever of these mode(s) of public engagement they think best without external judicial review [Reflexive]. They also permit agencies to collaborate with one another and the public [Legally Binding Authority]. Furthermore, agencies would be required to create and fund a staffed public participation specialist who coordinates community engagement and trains agency personnel in participatory practices. The city charter additionally requires city governments to establish Citizen Advisory Bodies with powers to set agendas and recommend policy; it also requires "adequate administrative support," including training, space, and staff [Legally Binding Responsibility, Tangible Support]. Bingham (2010) further proposes a federal Collaborative Governance Act to complement these provisions, and Bingham et al. (2005) identify ways that the 1996 Negotiated Rulemaking Act and Administrative Dispute Resolution Act could be strengthened to enhance public-government collaboration through nontraditional forms of community-based governance, such as quasi-legislative and quasi-judicial activities like participatory budgeting and citizen fact finding.

Regional government, bridging organizations, and agreements Regional systems of governance (e.g., Wheeler 2000), bridging organizations (e.g., Gerlak and Heikkila 2011, Garmestani and Benson 2013), and conservation agreements (e.g., Arnold et al. 2014) sometimes emerge when existing governance processes and authorities are reorganized and refocused. In some cases, these entities create new opportunities for emergence, or provide new forms of authority, which enable more robust adaptive management, specifically for regional, transboundary, or multisector water problems (Margerum 2008, Larson et al. 2013).

For example, when a private dam owner applied to the Federal Energy Regulatory Commission to relicense a hydroelectric dam on the Platte River system in Nebraska, USA (Aiken 1999), this opened a window for various stakeholders to protest water and species management under the Endangered Species and Clean Water Acts, triggering prolonged negotiations, which ultimately led to formation of regional compacts and governing bodies, with new roles and powers (Birge et al. 2014). The goal of these new arrangements was to develop a regional program that would allow multiple water users (both state and interstate) to use the river without having those uses contested in court every time; the negotiations also clarified socio-political, legal, and institutional boundaries of the social-ecological dilemma, clarifying legal jurisdiction [Well-Defined Boundaries], and better identifying responsibilities [Legally Binding Responsibility]. Though imperfect, the resulting Platte River Recovery and 
Implementation Program (PRRIP), increased cooperation and adaptive capacity of these users, in their local and regional management of the river.

Three states, Nebraska, Wyoming, and Colorado, entered into the PRRIP, and established a polycentric, cooperative governing system to assist in local and regional adaptive management. A governing board consisting of representatives from each state, the U.S. Fish and Wildlife Service, the Bureau of Reclamation, two environmental representatives, and three water user representatives [Participatory Decision Making], reviews and directs the activities specified in the cooperative agreement [Internal Enforcement] (U.S. Department of the Interior 1997). The governing board also established special committees to oversee specific recovery and water management programs. These committees have adopted an adaptive management approach, in which management best practices would be empirically tested and periodically revised, as needed within specified time ranges [Legal Sunsets, Reflexive] (e.g., State of the Platte 2014).

Additional steps undertaken in Nebraska, further demonstrate state-reinforced self-governance. Nebraska's administration of surface and groundwater management was historically fragmented, with different stakeholders managing groundwater (elected boards of local users) vs. surface water (state of Nebraska). As such, crucial aspects of groundwater management, and integrated water management, were out of Nebraska's control, which meant Nebraska could not reliably uphold its obligation to the state partners of the agreement, jeopardizing trust. In 2004, the Nebraska Legislature corrected this limitation by adopting LB 962, which authorized the Department of Natural Resources to declare river basins as over/ fully appropriated [Legally Binding Authority] (Kelly 2010), which subsequently required local natural resources districts to adopt well moratoria, and develop integrated water management plans [Legally Binding Responsibility] (Birge et al. 2014). Nebraska state government also invested in hydrologic modeling and monitoring, which provided valuable hydrologic and usage data to resource districts and users at no cost, helping districts meet their new responsibilities [Tangible Support].

Although the Platte River case is more fragmented and less complete than Sarker's (2013) example of irrigation in Japan, it spans multiple types of legal processes and incorporates many elements of state-reinforced self-governance for this particular governance issue. In summary, the examples in the section illustrate some concrete manifestations of the principles, providing an initial proof of concept, which is open to future exploration.

\section{CONCLUSIONS: LIMITATIONS AND FUTURE DIRECTIONS}

We have strived to outline legal and institutional design principles that may foster the emergence of adaptive governance within various centers of governance activity. However, we acknowledge that these principles are preliminary, and that adaptive governance is both fundamentally uncertain and fraught with complex challenges typical of governance in SESs (Chaffin et al. 2014a). To conclude, we discuss some of the more important theoretical and practical challenges for the current framework, and identify future directions for research.
First, although we addressed design principles that may enable adaptive governance, and provided some concrete examples, we did not address how to encourage society to adopt these principles. That is likely to be a nonlinear and contentious process (DeCaro et al. 2017), which will depend on the specific situations unfolding in a given SES (e.g., Wheeler 2000). The principles outlined herein provide a starting point, a framework within which to work. We suspect that the design principles are configurative and that supporting more of these enabling conditions will increase the potential for emergence and adaptive governance (e.g., DeCaro et al. 2015). Many factors influence emergence. Leaders with vision, endurance, and political savvy, also play a significant role (Olsson et al. 2004, Westley et al. 2013). However, it is not clear what leads decision makers to advance toward adaptation rather than rigidity or maladaptation (Moser and Ekstrom 2010, DeCaro et al. 2017).

Second, we believe civic education is essential to adaptive governance: the stated design principles cannot fully succeed if elected officials and citizens do not understand, and appreciate, the need for both adaptation and self-governance (Shivakumar 2005, DeCaro et al. 2017). Vincent (1997) and Elinor Ostrom (1998) proposed that self-governance in the U.S. is adversely affected by a public education system that (a) emphasizes relatively passive, indirect forms of democratic participation and (b) does not teach citizens the philosophical basis, or practical methods, of more direct collaborative approaches, like grassroots organizing and community-based governance. Bingham et al. (2008), Lydon et al. (2010), and others provide concrete examples, educational guidelines, and training for cooperative problemsolving and leadership in an era of "new governance," which may be essential elements of civic education designed to enable adaptive governance.

Third, although this synthesis is grounded in broad disciplinary traditions, multiple case studies (e.g., Cosens et al. 2014), and extensive literature review, it is ultimately based on a subset of possible legal frameworks, institutional contexts, and cases. Additional research is needed to test these ideas in field and laboratory experiments, and in actual field trials in both similar and contrasting social and environmental governance contexts. For example, although the literature used herein spanned developed and developing nations with different cultural backgrounds (e.g., Ostrom 1990, Cox et al. 2010), the case examples explored herein are all from a developed world context, generally Western democratic culture. Design principles do not apply directly in different cultural contexts or SESs; they must be translated and adapted (e.g., Agrawal and Ribot 2014, DeCaro and Stokes 2013). Future work is needed to investigate if and how these ideas translate to more diverse contexts, with potentially different social norms, ecological issues, and governance systems (e.g., Ostrom 2007), including laws (Garmestani and Allen 2014).

Fourth, for simplicity, we have portrayed "rigid" environmental laws and governance systems primarily as an obstacle to adaptive governance, despite existing evidence to the contrary. Policy entrepreneurs sometimes use existing rigidities as a "hammer" with which to trigger novel changes. For example, Freeman (2010:410) argues that the primary value of the Endangered Species Act is its ability to induce crisis from rigidity, forcing "the reconfiguration of existing ways" (e.g., Chaffin et al. 2014b). Thus, 
existing shortcomings or rigidities in environmental governance interact with other system components in complex ways.

Generally speaking, future research needs to descriptively investigate how emergence frontiers are shaped and constrained by a constellation of legal, institutional, and social-ecological factors. Case studies can focus greater attention on this particular question. We have focused on aspects of law and institutions that directly support self-organization. However, many other aspects of law and institutions influence adaptation and selforganization, by affecting flexibility and governance authority, perhaps more indirectly: for example, common law (Ruhl 2011, Green et al. 2014), property law (Doremus and Hanemann 2008), and law governing judicial decision making (e.g., Arnold and Gunderson 2013). Furthermore, legal instruments operating in different domains and at a variety of scales interact; these effects require more attention. For instance, grassroots watershed organizations often use the Clean Water Act as a basis for their legal authority to monitor and enforce water management activities of actors in their watersheds (e.g., Arnold et al. 2014). In essence, this creates indirect state-reinforced self-governance, or legally binding authority, which better enables grassroots organizations to emerge and self-organize. Investigating these kinds of issues descriptively, using the enclosed analytical conventions, should provide a rigorous test of proposed design principles, identify important areas for refinement and addition, and more fully inform adaptive governance.

We must also increase our understanding of how to integrate legal instruments to enable adaptive governance in transboundary environmental problems that span multiple jurisdictions, sectors, and social-ecological (sub)systems (Young 2008, Green et al. 2014, 2015). What design principles could support emergence and effective cooperation across scales, or jurisdictions, when sectors, problems, and legal and institutional frameworks need to be linked?

We have addressed this question in terms of bridging organizations and agreements (e.g., Platte River Recovery and Implementation Program; Birge et al. 2014). We essentially argued that participatory decision making, legally binding responsibility and authority, and internal dispute resolution and enforcement mechanisms (Table 1) may create conditions, which eventually generate broader integration in the form of partnerships, compacts, and collaboratives. However, cross-scale integration is likely to be challenging, as illustrated by the existence of so few examples of success, and tendency to compartmentalize governance problems. For example, in Sarker's (2013) case study, water irrigation in Japan is governed by a polycentric system of state-reinforced self-governance, but rice production is governed centrally by more traditional government mechanisms. Many broad-scale problems are similarly fragmented. For example, U. S. coastal reef management (Green et al. 2014) is governed by a loose network of international law, policies, treaties, organizations, and legal frameworks, development grants, research support, and voluntary commitments; however, there is no substantial sector integration (e.g., land-use law remains separate from coastal reef management), legally binding authority and responsibility of scale, or tangible internal enforcement to ensure robust cooperation. This has resulted in noted failures of ecosystem management (e.g., De'ath et al. 2012,
Chen and Ganapin 2016). Future research is needed to determine whether this is the best societies can do at such broad scales given complexity of integration, or if not, what role design features like those outlined herein may play (e.g., Berkes 2007, Stern 2011).

We therefore present the current article as a working hypothesis, and we encourage legal and institutional scholars to explore the implications of this perspective for state-reinforced selfgovernance and adaptive environmental governance.

Responses to this article can be read online at: http://www.ecologyandsociety.org/issues/responses. $\mathrm{php} / 9036$

\section{Acknowledgments:}

We thank research assistant Caroline Griggs for help in preparing figures for publication and Barbara Cosens for feedback on an early draft of this article. This work was supported by the National SocioEnvironmental Synthesis Center (SESYNC) under funding from the National Science Foundation DBI-1052875. The views expressed in this paper are those of the authors and do not represent the views or policies of the U.S. Environmental Protection Agency.

\section{LITERATURE CITED}

Adelman, D., and K. Engel. 2011. Reorienting state climatechange policies to induce technological change. Pages 163-179 in E. Schlager and K. Engel, editors. Navigating climate change policy: the opportunities of federalism. The University of Arizona Press, Tucson, Arizona, USA.

Agrawal, A., and J. Ribot. 2014. Are Ostrom's design principles sufficient for design? Policy Matters 19:111-115.

Aiken, J. D. 1999. Balancing endangered species protection and irrigation water rights: the Platte River cooperative agreement. Great Plains Natural Resources Journal 3(Spring):119-158.

Allen, C. R., and A. S. Garmestani. 2015. Adaptive management of social-ecological systems. Springer, Dordrecht, The Netherlands. http://dx.doi.org/10.1007/978-94-017-9682-8

Anderies, J. M., and M. A. Janssen. 2013. Robustness of socialecological systems: implications for public policy. Policy Studies Journal 41(3):513-536. http://dx.doi.org/10.1111/psj.12027

Anderies, J. M., M. A. Janssen, and E. Ostrom. 2004. A framework to analyze the robustness of social-ecological systems from an institutional perspective. Ecology and Society 9(1):18. http://dx. doi.org/10.5751/es-00610-090118

Armitage, D. 2007. Governance and the commons in a multi-level world. International Journal of the Commons 2(1):7-32. http://dx. doi.org/10.18352/ijc. 28

Arnold, C. A. (T.), O. O. Green, D. DeCaro, A. Chase, and J.-G. Ewa. 2014. The social-ecological resilience of an eastern urbansuburban watershed: the Anacostia River Basin. Idaho Law Review 51(1):29-90.

Arnold, C. A., and L. H. Gunderson. 2013. Adaptive law and resilience. Environmental Law Reporter 43:10426-10443. 
Arnstein, S. R. 1969. A ladder of citizen participation. Journal of the American Institute of Planners 35:216-224. http://dx.doi. org/10.1080/01944366908977225

Bardhan, P. 2000. Irrigation and cooperation: an empirical analysis of 48 irrigation communities in South India. Economic Development and Cultural Change 48(4):847-865. http://dx.doi. org/10.1086/452480

Benson, D., A. Jordan, H. Cook, and L. Smith. 2013. Collaborative environmental governance: are watershed partnerships swimming or are they sinking? Land Use Policy 30 (1):748-757. http://dx.doi.org/10.1016/j.landusepol.2012.05.016

Benson, M. H., D. Llewellyn, R. Morrison, and M. Stone. 2014. Water governance challenges in New Mexico's Middle Rio Grande Valley: a resilience assessment. Idaho Law Review 51 (1):195-228. http://dx.doi.org/10.2139/ssrn.2464387

Berkes, F. 2007. Community-based conservation in a globalized world. Proceedings of the National Academy of Sciences 104 (39):15188-15193. http://dx.doi.org/10.1073/pnas.0702098104

Bingham, L. B. 2009. Collaborative governance: emerging practices and the incomplete legal framework for public and stakeholder voice. Journal of Dispute Resolution 2(2):1-58.

Bingham, L. B. 2010. The next generation of administrative law: building the legal infrastructure for collaborative governance. Wisconsin Law Review 297(2).

Bingham, L. B., T. Nabatchi, and R. O'Leary. 2005. The new governance: practices and processes for stakeholder and citizen participation in the work of government. Public Administration Review 65(5):547-558. http://dx.doi.org/10.1111/j.1540-6210.2005.00482. $\underline{\mathrm{x}}$

Bingham, L. B., J. Sandfort, and R. O’Leary. 2008. Learning to do and doing to learn: teaching managers to collaborate in networks. Pages 270-286 in L. B. Bingham and R. O'Leary, editors. Big ideas in collaborative public management. Taylor and Francis, New York, New York, USA.

Birge, H. E., C. R. Allen, R. K. Craig, A. S. Garmestani, J. A. Hamm, C. Babbitt, K. Nemec, and E. Schlager. 2014. Socialecological resilience and law in the Platte River Basin. Idaho Law Review 51(1):229-327.

Brunner, R. D., T. A. Steelman, L. Coe-Juell, C. M. Cromley, C. M. Edwards, and D. W. Tucker. 2005. Adaptive governance: integrating science, policy, and decision making. Columbia University Press, New York, New York, USA.

Bullard, R. D., and G. S. Johnson. 2000. Environmental justice: grassroots activism and its impact on public policy decision making. Journal of Social Issues 56(3):555-578.

Cash, D. W., W. N. Adger, F. Berkes, P. Garden, L. Lebel, P. Olsson, L. Pritchard, and O. Young. 2006. Scale and cross-scale dynamics: governance and information in a multilevel world. Ecology and Society 11(2):8. http://dx.doi.org/10.5751/es-01759-110208

Castro, P. 2012. Legal innovation for social change: exploring change and resistance to different types of sustainability laws. Political Psychology 33(1):105-121. http://dx.doi.org/10.1111/ j.1467-9221.2011.00863.x
Chaffin, B. C., R. K. Craig, and H. Gosnell. 2014b. Resilience, adaptation, and transformation in the Klamath River Basin social-ecological system. Idaho Law Review 51(1):157-183.

Chaffin, B. C., and H. Gosnell, and B. A. Cosens. 2014a. A decade of adaptive governance scholarship: synthesis and future directions. Ecology and Society 19(3):56. http://dx.doi. org/10.5751/ES-06824-190356

Chaffin, B. C., and L. H. Gunderson. 2016. Emergence, institutionalization and renewal: rhythms of adaptive governance in complex social-ecological systems. Journal of Environmental Management 165:81-87. http://dx.doi.org/10.1016/j.jenvman.2015.09.003

Chen, S., and S. Ganapin. 2016. Polycentric coastal and ocean management in the Caribbean Sea Large Marine Ecosystem: harnessing community-based actions to implement regional frameworks. Environmental Development 17(1):264-276. http:// dx.doi.org/10.1016/j.envdev.2015.07.010

Clark, W. C., D. D. Jones, and C. S. Holling. 1979. Lessons for ecological policy design: a case study of ecosystem management. Ecological Modelling 7(1):1-53. http://dx.doi.org/10.1016/0304-3800 (79)90008-5

Clarvis, M. H., A. Allan, and D. M. Hannah. 2014. Water, resilience and the law: from general concepts and governance design principles to actionable mechanisms. Environmental Science and Policy 43:98-110. http://dx.doi.org/10.1016/j. envsci.2013.10.005

Clement, F. 2010. Analysing decentralised natural resource governance: proposition for a "politicised" institutional analysis and development framework. Policy Sciences 43(2):129-156. http://dx.doi.org/10.1007/s11077-009-9100-8

Cole, D. H., and M. D. McGinnis. 2015. Elinor Ostrom and the Bloomington School of Political Economy, Vol. 1: polycentricity in public administration and political science. Lexington Books, Lanham, Maryland, USA.

Cosens, B. A. 2013. Legitimacy, adaptation, and resilience in ecosystem management. Ecology and Society 18(1):3. http://dx. doi.org/10.5751/ES-05093-180103

Cosens, B. A., R. K. Craig, S. Hirsch, C. A. (T.) Arnold, M. H. Benson, D. A. DeCaro, A. S. Garmestani, H. Gosnell, J. Ruhl, and E. Schlager. 2017. The role of law in adaptive governance. Ecology and Society 22(1):30. http://dx.doi.org/10.5751/ es-08731-220130

Cosens, B., and A. Fremier. 2014. Assessing system resilience and ecosystem services in large river basins: a case study of the Columbia River Basin. Idaho Law Review 51(1):91-125.

Cosens, B. A., L. Gunderson, and B. Chaffin. 2014. The adaptive water governance project: assessing law, resilience and governance in regional social-ecological water systems facing changing climate. Idaho Law Review 51(1):1-27.

Cox, M. 2014. Applying a social-ecological system framework to the study of the Taos Valley irrigation system. Human Ecology 42(2):311-324. http://dx.doi.org/10.1007/s10745-014-9651-y

Cox, M., G. Arnold, and S. V. Tomás. 2010. A review of design principles for community-based natural resource management. 
Ecology and Society 15(4):38. http://dx.doi.org/10.5751/ ES-03704-150438

Craig, R. K. 2010. Stationarity is dead: long live transformation: five principles for climate change adaptation law. Harvard Environmental Law Review 31:9-75.

Craig, R. K., A. S. Garmestani, C. R. Allen, C. A. Arnold, H. Birgé, D. A. DeCaro, A. K. Fremier, H. Gosnell, and E. Schlager. 2017. Balancing stability and flexibility in adaptive governance: an analysis of tools available in U.S. environmental law. Ecology and Society: in press

Craig, R. K. and J. B. Ruhl. 2014. Designing administrative law for adaptive management. Vanderbilt Law Review 67(1):1-87. http://dx.doi.org/10.2139/ssrn.2222009

Craik, A. N., and J. F. DiMento. 2008. Environmental cooperation in the (partially) disaggregated state: lessons from the Security and Prosperity Partnership of North America. Chicago Journal of International Law 8:479. http://dx.doi. org/10.2139/ssrn.1285571

Davidson, D. J. 2010. The applicability of the concept of resilience to social systems: some sources of optimism and nagging doubts. Society and Natural Resources 23:1135-1149. http://dx.doi. org/10.1080/08941921003652940

De'ath, G., K. E. Fabricius, H. Sweatman, and M. Puotinen. 2012. The 27-year decline of coral cover on the Great Barrier Reef and its causes. Proceedings of the National Academy of Sciences 109 (44):17995-17999. http://dx.doi.org/10.1073/pnas.1208909109

DeCaro, D. A., C. A. (T.) Arnold, E. F. Boamah, and A. S. Garmestani. 2017. Understanding and applying principles of social cognition and decision making in adaptive environmental governance. Ecology and Society 22(1):33. http://dx.doi. org/10.5751/es-09154-220133

DeCaro, D. A., M. A. Janssen, and A. Lee. 2015. Synergistic effects of voting and enforcement on internalized motivation to cooperate in a resource dilemma. Judgment and Decision Making 10(6):511-537.

DeCaro, D. A., and M. K. Stokes. 2013. Public participation and institutional fit: a social-psychological perspective. Ecology and Society 18(4):40. http://dx.doi.org/10.5751/ES-05837-180440

Dietz, T., E. Ostrom, and P. C. Stern. 2003. The struggle to govern the commons. Science 302:1907-1912. http://dx.doi.org/10.1126/ science.1091015

Dietz, T., E. A. Rosa, and R. York. 2009. Environmentally efficient well-being: rethinking sustainability as the relationship between human well-being and environmental impacts. Human Ecology Review 16(1):114-123.

Doremus, H. 2010. The Endangered Species Act: static law meets dynamic world. Washington University Journal of Law and Policy 32:175. [online] URL: http://scholarship.law.berkeley.edu/ facpubs/790

Doremus, H., and M. Hanemann. 2008. The challenges of dynamic water management in the American West. UCLA Journal of Environmental Law \& Policy 26(2):55-75.
Eberlein, B., and A. L. Newman. 2008. Escaping the international governance dilemma? Incorporated transgovernmental networks in the European Union. Governance 21(1):25-52. http://dx.doi. org/10.1111/j.1468-0491.2007.00384.x

Engel, K. H. 2006. Harnessing the benefits of dynamic federalism in environmental law. Emory Law Journal 56:159.

Epstein, G., J. Pittman, S. M. Alexander, S. Berdej, T. Dyck, U. Kreitmair, K. J. Raithwell, S. Villamayor-Tomas, J. Vogt, and D. Armitage. 2015. Institutional fit and the sustainability of socialecological systems. Current Opinion in Environmental Sustainability 14:34-40. http://dx.doi.org/10.1016/j.cosust.2015.03.005

Fleischman, F. D., K. Boenning, G. A. Garcia-Lopez, S. Mincey, M. Schmitt-Harsh, K. Daedlow, M. Lopez, X. Basurto, B. Fischer, and E. Ostrom. 2010. Disturbance, response, and persistence in self-organized forested communities: analysis of robustness and resilience in five communities in southern Indiana. Ecology and Society 15(4):9. http://dx.doi.org/10.5751/ES-03512-150409

Folke, C., T. Hahn, P. Olsson, and J. Norberg. 2005. Adaptive governance of social-ecological systems. Annual Review of Environment and Resources 30:441-473. http://dx.doi.org/10.1146/ annurev.energy.30.050504.144511

Folke, C., L. Pritchard, F. Berkes, J. Colding, and U. Svedin. 2007. The problem of fit between ecosystems and institutions: ten years later. Ecology and Society 12(1):30. http://dx.doi.org/10.5751/ ES-02064-120130

Food and Agriculture Organization (FAO). 2012. State of the worlds' forests. FAO, Rome, Italy.

Freeman, D. 2010. Implementing the Endangered Species Act on the Platte Basin Water Commons. University Press of Colorado, Boulder, Colorado, USA.

Galusha, D. 2002. Liquid assets: a history of New York City's water system. Purple Mountain Press, Fleischmanns, New York, USA.

Garmestani, A. S., and C. R. Allen, editors. 2014. Socialecological resilience and law. Columbia University Press, New York, New York, USA. http://dx.doi.org/10.7312/garm16058

Garmestani, A. S., and M. H. Benson. 2013. A framework for resilience-based governance of social-ecological systems. Ecology and Society 18(1):9. http://dx.doi.org/10.5751/ES-05180-180109

Garrick, D., L. De Stefano, F. Fung, J. Pittock, E. Schlager, M. New, and D. Connell. 2013. Managing hydroclimatic risks in federal rivers: a diagnostic assessment. Philosophical Transactions of the Royal Society A 371(2002). http://dx.doi.org/10.1098/ rsta.2012.0415

Genskow, K. D., and S. M. Born. 2006. Organizational dynamics of watershed partnerships: a key to integrated water resources management. Journal of Contemporary Water Research \& Education 135(1):56-64. http://dx.doi.org/10.1111/j.1936-704x.2006. mp135001007.x

Gerlak, A. K., and T. Heikkila. 2011. Building a theory of learning in collaboratives: evidence from the Everglades Restoration Program. Journal of Public Administration Research and Theory 21:619-644. http://dx.doi.org/10.1093/jopart/muq089 
Gianetto, D. A., and B. Heydari. 2015. Catalysts of cooperation in system of systems: the role of diversity and network structure. IEEE Systems Journal 9(1):303-311. http://dx.doi.org/10.1109/ jsyst.2013.2284959

Goddard, M. A., A. J. Dougill, and T. G. Benton. 2010. Scaling up from gardens: biodiversity conservation in urban environments. Trends in Ecological Evolution 25(2):90-98. http:// dx.doi.org/10.1016/j.tree.2009.07.016

Green, O. O., A. S. Garmestani, C. R. Allen, L. H. Gunderson, J. B. Ruhl, C. A. Arnold, N. A. J. Graham, B. Cosens, D. G. Angeler, B. C. Chaffin, and C. S. Holling. 2015. Barriers and bridges to the integration of social-ecological resilience and law. Frontiers in Ecology and the Environment 13(6):332-337. http://dx. doi.org/10.1890/140294

Green, O. O., A. S. Garmestani, M. E. Hopton, and M. T. Heberling. 2014. A multi-scalar examination of law for sustainable ecosystems. Sustainability 6(6):3534-3551. http://dx. doi.org/10.3390/su6063534

Gunderson, L. H. 2000. Ecological resilience - in theory and application. Annual Review of Ecology and Systematics 31:425-439. http://dx.doi.org/10.1146/annurev.ecolsys.31.1.425

Gunderson, L. H., A. Garmestani, K. W. Rizzardi, J. B. Ruhl, and A. Light. 2014. Escaping a rigidity trap: governance and adaptive capacity to climate change in the Everglades social ecological system. Idaho Law Review 51:127-156.

Gunderson, L. H., and C. S. Holling, editors. 2002. Panarchy: understanding transformations in human and natural systems. Island Press, Washington, D.C., USA.

Gunderson, L. H., C. S. Holling, and S. S. Light, editors. 1995. Barriers and bridges to the renewal of ecosystems and institutions. Columbia University Press, New York, New York, USA.

Heikkila, T., E. Schlager, and M. W. Davis. 2011. The role of crossscale institutional linkages in common pool resource management: assessing interstate river compacts. Policy Studies Journal 39(1):121-145. http://dx.doi.org/10.1111/j.1541-0072.2010.00399. $\underline{x}$

Holling, C. S. 1973. Resilience and stability of ecological systems. Annual Review of Ecology and Systematics 4:1-23. http://dx.doi. org/10.1146/annurev.es.04.110173.000245

Holling, C. S., editor. 1978. Adaptive environmental assessment and management. John Wiley \& Sons, New York, New York, USA.

Holling, C. S. 1986. The resilience of terrestrial ecosystems: local surprise and global change. Sustainable Development of the Biosphere. Pages 292-317 in W. C. Clark and R. E. Munn, editors. Sustainable development of the biosphere. Cambridge University Press, Cambridge, UK.

Holling, C. S. 2001. Understanding the complexity of economic, ecological, and social systems. Ecosystems 4(5):390-405. http:// dx.doi.org/10.1007/s10021-001-0101-5

International Union for Conservation of Nature and Natural Resources (IUCN). 1980. World conservation strategy. Living resource conservation for sustainable development. IUCN, Gland, Switzerland.
International Union for Conservation of Nature and Natural Resources (IUCN). 2008. Shaping a sustainable future: The IUCN Programme 2009-2012. IUCN, Gland, Switzerland. [online] URL: https://cmsdata.iucn.org/downloads/ iucn programme 20092012 dfc.pdf

Kelly, M. 2010. Nebraska's evolving water law: overview of challenges and opportunities. Platte Institute for Economic Research. [online] URL: http:www.platteinstitute.org/Library/ docLib/20100927 Kelly Paper - FINAL.pdf

Koontz, T. M., and E. M. Johnson. 2004. One size does not fit all: matching breadth of stakeholder participation to watershed group accomplishments. Policy Sciences 37(2):185-204. http://dx. doi.org/10.1023/b:olic.0000048532.94150.07

Larson, K. L., A. Wiek, and L. W. Keeler. 2013. A comprehensive sustainability appraisal of water governance in Phoenix, AZ. Journal of Environmental Management 116:58-71. http://dx.doi. org/10.1016/j.jenvman.2012.11.016

Lubell, M., M. Schneider, J. T. Scholz, and M. Mete, M. 2002. Watershed partnerships and the emergence of collective action institutions. American Journal of Political Science 46(1):148-163. http://dx.doi.org/10.2307/3088419

Lydon, M., D. Bartman, R. Woudstra, and A. Khawarzad. 2010. Tactical urbanism: short term action: long term change. Volume 1. Issuu, Palo Alto, California, USA.

Margerum, R. D. 2008. A typology of collaboration efforts in environmental management. Environmental Management 41:487-500. http://dx.doi.org/10.1007/s00267-008-9067-9

Marshall, G. 2007. Nesting, subsidiarity, and community-based environmental governance beyond the local scale. International Journal of the Commons 2(1):75-97. http://dx.doi.org/10.18352/ ijc. 50

McGinnis, M. D., and E. Ostrom. 2014. Social-ecological system framework: initial changes and continuing challenges. Ecology and Society 19(2):30. http://dx.doi.org/10.5751/ES-06387-190230

Millennium Ecosystem Assessment (MEA). 2005. Ecosystems and human well-being: synthesis. Island Press, Washington, D.C., USA.

Moser, S. C., and J. A. Ekstrom. 2010. A framework to diagnose barriers to climate change adaptation. Proceedings of the National Academy of Sciences 107(51):22026-22031. http://dx.doi. org/10.1073/pnas.1007887107

National Civic League (NCL). 2013. Making public participation legal. [online] URL: http://ncdd.org/rc/wp-content/uploads/ MakingP2Legal.pdf

Olsson, P., C. Folke, and F. Berkes. 2004. Adaptive comanagement for building resilience in social-ecological systems. Environmental Management 34(1):75-90. http://dx.doi.org/10.1007/s00267-003-0101-7

Orts, E. W. 1995. A reflexive model of environmental regulation. Business Ethics Quarterly 5(4):779-794 http://dx.doi.org/10.2307/3857414

Ostrom, E. 1965. Public entrepreneurship: a case study in ground water management. Dissertation, University of California at Los Angeles, Los Angeles, California, USA. 
Ostrom, E. 1990. Governing the commons: the evolution of institutions for collective action. Cambridge University Press, Cambridge, UK. http://dx.doi.org/10.1017/CBO9780511807763

Ostrom, E. 1992. Crafting institutions for self-governing irrigation systems. Institute for Contemporary Studies Press, San Francisco, California, USA.

Ostrom, E. 1998. A behavioral approach to the rational choice theory of collective action: presidential address, American Political Science Association, 1997. American Political Science Review 91:1-22. http://dx.doi.org/10.2307/2585925

Ostrom, E. 2000. The danger of self-evident truths. PS: Political Science \& Politics 33(01):33-46. http://dx.doi.org/10.1017/ $\underline{\mathrm{S} 1049096500055451}$

Ostrom, E. 2005. Understanding institutional diversity. Princeton University Press, Princeton, New Jersey, USA.

Ostrom, E. 2007. A diagnostic approach for going beyond panaceas. Proceedings of the National Academy of Sciences 104 (39):15181-15187. http://dx.doi.org/10.1073/pnas.0702288104

Ostrom, E. 2009. A general framework for analyzing sustainability of social-ecological systems. Science 325:419-422. http://dx.doi.org/10.1126/science.1172133

Ostrom, E. 2010. Beyond markets and states: polycentric governance of complex economic systems. American Economic Review 100:641-672. http://dx.doi.org/10.1257/aer.100.3.641

Ostrom, E. 2014. Do institutions for collective action evolve? Journal of Bioeconomics 16:3-30. http://dx.doi.org/10.1007/ $\underline{\text { s10818-013-9154-8 }}$

Ostrom, V. 1971. The political theory of a compound republic: designing the American experiment. Second edition. Institute for Contemporary Studies Press, San Francisco, California, USA.

Ostrom, V. 1994. The meaning of American federalism: constituting a self-governing society. Institute for Contemporary Studies Press, San Francisco, California, USA.

Ostrom, V. 1997. The meaning of democracy and the vulnerability of democracies: a response to Tocqueville's challenge. University of Michigan Press, Ann Arbor, Michigan, USA. http://dx.doi. org/10.3998/mpub.15021

Ostrom, V. 1999. Polycentricity. (Parts 1 and 2). Pages 52-74 and 119-138 in M. D. McGinnis, editor. Polycentricity and local public economies. University of Michigan Press, Ann Arbor, Michigan, USA.

Pahl-Wostl, C. 2009. A conceptual framework for analysing adaptive capacity and multi-level learning processes in resource governance regimes. Global Environmental Change 19(3):354-365. http://dx.doi.org/10.1016/j.gloenvcha.2009.06.001

Platt, R. H., P. K. Barten, and M. J. Pfeffer. 2000. A full, clean glass? Managing New York City's watershed. Environment: Science and Policy for Sustainable Development 42(5):8-20. http:// dx.doi.org/10.1080/00139150009604886

Poteete, A. R., M. A. Janssen, and E. Ostrom, editors. 2010. Pushing the frontiers of the theory of collective action and the commons. Pages 215-247 in Working together: collective action, the commons, and multiple methods in practice. Princeton University Press, Princeton, New Jersey, USA.

Prager, K. 2010. Local and regional partnerships in natural resource management: the challenge of bridging institutional levels. Environmental Management 46:711-724. http://dx.doi. org/10.1007/s00267-010-9560-9

Resilience Alliance. 2010. Assessing resilience in social-ecological systems: workbook for practitioners. Version 2.0. [online] URL: http://www.resalliance.org/files/ResilienceAssessmentV2 2.pdf

Resnik, J., J. Civin, and J. Frueh. 2011. Changing the climate: the role of translocal organizations of government actors (TOGAs) in American federalism(s). Pages 120-143 in E. Schlager, K. Engel, and S. Rider, editors. Navigating climate change policy: the opportunities of federalism. University of Arizona Press, Tucson, Arizona, USA.

Ruhl, J. B. 2009. Climate change and the endangered species act: building bridges to the no-analog future. Environmental Law and Policy Annual Review 39:10735-10751.

Ruhl, J. B. 2011. General design principles for resilience and adaptive capacity in legal systems: applications to climate change adaptation law. North Carolina Law Review 89:1374-1401.

Sabatier, P. A., W. Focht, M. Lubell, Z. Trachtenberg, A. Vedlitz, and M. Matlock. 2005. Swimming upstream: collaborative approaches to watershed management. The MIT Press, Cambridge, Massachusetts, USA.

Sarker, A. 2013. The role of state-reinforced self-governance in averting the tragedy of the irrigation commons in Japan. Public Administration 91(3):727-743 http://dx.doi.org/10.1111/padm.12011

Sarker, A., T. Ikeda, T. Abe, and K. Inoue. 2015. Design principles for managing coastal fisheries commons in present-day Japan. Ecological Economics 117:32-38. http://dx.doi.org/10.1016/j. ecolecon.2015.06.019

Sarker, A., T. Itoh, R. Kada, T. Abe, M. Nakashima, and G. Herath. 2014. User self-governance in a complex policy design for managing water commons in Japan. Journal of Hydrology 510:246-258. http://dx.doi.org/10.1016/j.jhydrol.2013.12.034

Schlager, E., K. Engel, and S. Rider, editors. 2011. Navigating climate change policy: the opportunities of federalism. The University of Arizona Press, Tucson, Arizona, USA.

Schlager, E., and T. Heikkila. 2011. Left high and dry? Climate change, common-pool resource theory, and adaptability of Western water compacts. Public Administration Review 71 (3):461-470. http://dx.doi.org/10.1111/j.1540-6210.2011.02367.x

Schlager, E., T. Heikkila, and C. Case. 2012. The costs of compliance with interstate agreements: lessons from water compacts in the western United States. Publius: The Journal of Federalism 42(3):494-515. http://dx.doi.org/10.1093/publius/ pjs017

Schultz, L., C. Folke, H. Österblom, and P. Olsson. 2015. Adaptive governance, ecosystem management, and natural capital. Proceedings of the National Academy of Sciences 112 (24):7369-7374. http://dx.doi.org/10.1073/pnas. 1406493112 
Shivakumar, S. 2005. The constitution of development: crafting capabilities for self-governance. Palgrave Macmillan, New York, New York, USA. http://dx.doi.org/10.1057/9781403982117

Stern, P. C. 2011. Design principles for global commons: natural resources and emerging technologies. International Journal of the Commons 5(2):213-232. http://dx.doi.org/10.18352/ijc.305

Teubner, G. 1983. Substantive and reflexive elements in modern law. Law and Society Review 17(2):239-286. http://dx.doi. org/10.2307/3053348

Thomson, V. E., and V. Arroyo. 2011. Upside-down cooperative federalism: climate change policymaking and the states. Virginia Environmental Law Journal 29(1):1-61.

Tobin, G. A. 1999. Sustainability and community resilience: the holy grail of hazards planning? Environmental Hazards 1:13-25. http://dx.doi.org/10.3763/ehaz.1999.0103

Tyler, T. R. 1990. Why people obey the law. Yale University Press, New Haven, Connecticut, USA.

Tyler, T. R. 2006. Psychological perspectives on legitimacy and legitimization. Annual Review of Psychology 57:375-400. http:// dx.doi.org/10.1146/annurev.psych.57.102904.190038

UNESCO. 2015. The UN World Water Development Report 2015, water for a sustainable world. UNESCO, Paris, France. [online] URL: http://www.unesco.org/new/en/natural-sciences/environment/ water/wwap/wwdr/2015-water-for-a-sustainable-world/

U.S. Department of the Interior. 1997. Cooperative agreement for Platte River research and other efforts relating to endangered species habitats along the Central Platte River Nebraska. U.S. Printing Office, Washington, D.C., USA

Westley, F. R, P. Olsson, C. Folke, T. Homer-Dixon, and H. Vredenburg, D. Loorbach, J. Thompson, M. Nilsson, E. Lambin, J. Sendzimir, B. Banerjee, V. Galaz, and S. van der Leeuw. 2011. Tipping toward sustainability: emerging pathways of transformation. AMBIO 40:762-80 http://dx.doi.org/10.1007/ $\underline{\text { s13280-011-0186-9 }}$

Westley, F. R., O. Tjornbo, L. Schultz, P. Olsson, C. Folke, B. Crona and Ö. Bodin. 2013. A theory of transformative agency in linked social-ecological systems. Ecology and Society 18(3):27. http://dx.doi.org/10.5751/ES-05072-180327

Wheeler, S. M. 2000. Planning for metropolitan sustainability. Journal of Planning Education and Research 20(2):133-145. http:// dx.doi.org/10.1177/0739456x0002000201

Young, O. R. 2008. The architecture of global environmental governance: bringing science to bear on policy. Global Environmental Politics 8(1):14-32. http://dx.doi.org/10.1162/ glep.2008.8.1.14 